\title{
Pre-/during-/post-laser processes to enhance the adhesion and mechanical properties of thermal sprayed coatings with a reduced environmental impact
}

Citation for published version (APA):

Garcia - Alonso, D., Serres, N., Demian, C., Costil, S., Langlade, C., \& Coddet, C. (2011). Pre-/during-/post-laser processes to enhance the adhesion and mechanical properties of thermal sprayed coatings with a reduced environmental impact. Journal of Thermal Spray Technology, 20(4), 719-735. https://doi.org/10.1007/s11666011-9629-x

DOI:

10.1007/s11666-011-9629-x

Document status and date:

Published: 01/01/2011

Document Version:

Publisher's PDF, also known as Version of Record (includes final page, issue and volume numbers)

Please check the document version of this publication:

- A submitted manuscript is the version of the article upon submission and before peer-review. There can be important differences between the submitted version and the official published version of record. People interested in the research are advised to contact the author for the final version of the publication, or visit the $\mathrm{DOI}$ to the publisher's website.

- The final author version and the galley proof are versions of the publication after peer review.

- The final published version features the final layout of the paper including the volume, issue and page numbers.

Link to publication

\footnotetext{
General rights

- You may freely distribute the URL identifying the publication in the public portal. follow below link for the End User Agreement:

www.tue.nl/taverne

Take down policy

If you believe that this document breaches copyright please contact us at:

openaccess@tue.nl

providing details and we will investigate your claim.
}

Copyright and moral rights for the publications made accessible in the public portal are retained by the authors and/or other copyright owners and it is a condition of accessing publications that users recognise and abide by the legal requirements associated with these rights.

- Users may download and print one copy of any publication from the public portal for the purpose of private study or research.

- You may not further distribute the material or use it for any profit-making activity or commercial gain

If the publication is distributed under the terms of Article 25fa of the Dutch Copyright Act, indicated by the "Taverne" license above, please 


\title{
Pre-/During-/Post-Laser Processes to Enhance the Adhesion and Mechanical Properties of Thermal-Sprayed Coatings with a Reduced Environmental Impact
}

\author{
D. Garcia-Alonso, N. Serres, C. Demian, S. Costil, C. Langlade, and C. Coddet
}

\author{
(Submitted November 30, 2010; in revised form January 30, 2011)
}

\begin{abstract}
Lasers have been used to improve the ultimate performance of thermal spray coatings for specific applications, but the full potential of additional laser treatments must be further explored. Laser treatments (auxiliary processes) can be applied before, during or after thermal spraying (main process), leading to a wide range of coating improvements (microstructure, adhesion, etc.). The aim of this review is to introduce the most significant laser treatments for thermal spray applications. The potential improvements for thermal spray coatings are illustrated by a selection of representative research cases. Laser pretreatments (ablation and texturing) promote coating/substrate adhesion and are suitable to prepare the surface of sensitive substrates such as aluminum, titanium, or magnesium alloys. The use of these techniques, which leads to several benefits such as surfaces free of grit-particle inclusions, directly improves the quality of coatings. Laser treatments applied simultaneously during the spraying process deeply modify the coatings microstructure. These hybrid technologies allow in situ laser melting of coatings, resulting in improved mechanical properties and enhanced wear and corrosion behaviors. Finally, laser posttreatments can improve coatings density and adhesion, and also induce phase transformations and structure refinement. As a summary, laser treatments seem particularly promising for improving the thermal spray coating microstructure and the coating/substrate adhesion. In addition, they offer a more environmentally friendly alternative to the conventional surface preparation treatments.
\end{abstract}

Keywords ablation, adhesion, laser treatments, mechanical properties, plasma spray, preheating, remelting hybrid process, surface modifications, texturing

\section{Introduction}

\subsection{Technological Context}

Plasma spraying is a technology used to produce thick coatings from feedstock powder materials. The quality of plasma-sprayed coatings depends on up to 50 different process parameters (Ref 1$)$, which mainly relate to the characteristics of the powder, powder injection, plasma gun, plasma flame, and substrate. For theoretical, practical, and economic reasons (e.g., parameter interdependence, time requirements, etc.), it is only possible to control some of those parameters. A maximum of 8 to 12

D. Garcia-Alonso, C. Demian, S. Costil, C. Langlade and C. Coddet, LERMPS, UTBM, Belfort, France; N. Serres, LGéCO-LISS, INSA, Strasbourg, France; C. Demian, LTm, Institut Carnot, Université de Bourgogne, Le Creusot, France; and C. Demian, Mechanical Engineering Faculty, Politehnica University of Timisoara, Timisoara, Romania. Contact e-mails: Diana.garcia.alonso@gmail.com and diana.garcia-alonso@utbm.fr.

parameters can actually be controlled in order to obtain the desired coating structure and in-service properties (Ref 2). However, the targeted coating characteristics cannot always be achieved due to the large number of process parameters combinations. Auxiliary systems can be used to uncouple some interrelated effects and allow for new degrees of freedom in the process control. For instance, laser treatments can be applied to improve specific coating properties at different stages of the thermal spraying process.

Thermal spray processes begin with surface preparation to ensure adequate coating/substrate adhesion. Conventionally, substrates are prepared using a two-step treatment: cleaning (degreasing) and roughening. In order to remove the organic substances present on the as-machined surfaces, the degreasing step uses solvents or chemicals which are potentially harmful for the operator and the environment. The roughening of the surface aims to improve the mechanical anchoring of the impinging particles which build up the coating. The most extended surface roughening technique is grit blasting. It produces large plastic deformations throughout the surface and induces microstructural changes in the immediate subsurface, which result in compressive residual stresses. Fatigue resistance is expected to increase as a result of the stress level in the subsurface region, fact that has been corroborated for materials such as pure titanium (Ref 3 ) or 316LVM stainless steel (Ref 4). However, the opposite 
trend has also been observed for other materials such as binary titanium alloys, whose fatigue limit has been reported to decrease by up to $40 \%$ after grit blasting (Ref 5,6). Another drawback of this method is that grit particles usually get entrapped on the substrate and subsequently compromise the coating performance. This effect is particularly important in the case of ductile substrates, which are likely to suffer a surface and subsurface embrittlement due to grit particles acting as tension concentrators. Last but not least, the use of sand or corundum (materials normally used as grit) has been linked with serious diseases such as silicosis, aluminosis, lung scarring, pneumoconiosis, or emphysema (Ref 7). For all these reasons, the viability of alternative techniques such as water/water-air jet (Ref 8), dry ice blasting (Ref 9), or laser (Ref 10) has been studied over the last decade. Among all options, laser is the only treatment which can be integrated with the thermal spray process allowing for a one-step coating process (combining surface preparation and coating deposition). Lasers also offer a better environmental option than conventional treatments. Reduced production time, surface activation, small thermal alteration and negligible residual deformation of the bulk material, and limited surface contamination, account among other advantages of laser hybrid options (Ref 11). In addition, laser treatments can be used for substrate preheating (Ref 12) before thermal spraying or to improve the coating properties (adhesion, density, etc.) afterward (Ref 13, 14). For instance, lasers can be used for surface alloying, which results in different compositions and microstructural changes of the coating/substrate interface. Fine homogeneous microstructures, high-solid solubility and formation of nonequilibrium and amorphous phases have also been reported (Ref 15,16$)$. However, the full potential of lasers in the field of thermal spraying still has to be explored.

\subsection{Environmental Context}

Over the last decades, the protection of the environment has become a main concern for most of the developed countries (Ref 17). For instance, the EU waste management strategies strongly regulate the disposal of chemicals since 2006 (Ref 18). The substitution of conventional wet deposition processes, which involve chemicals and potentially hazardous effluents, by alternative dry processes (such as thermal spraying or laser cladding) has been therefore encouraged in surface finishing. These recent environmental regulations on processes, materials and products are triggering new technology developments that, together with cost competition, will probably force significant changes in the near future. In this context, the implementation of new laser technologies is likely to increase.

A good example of this trend is the substitution of the electrodeposition process used for the production of hard chromium coatings (Ref 19). This wet process requires the use of $\mathrm{CrO}_{3}$ compounds (Ref 20), which are toxic, carcinogenic, and hazardous for the environment (Ref 21, 22). Depending on the application, a number of replacement technologies are available, comprising wet deposition technologies (e.g., trivalent chromium plating, nickelbased electroplating, electroless nickel, and nickel alloy coatings) and dry deposition technologies (e.g., microwelding, cladding, chemical vapor deposition (CVD), physical vapor deposition (PVD), and thermal spray technology) (Ref 23-25). Thermal spray has already been validated as an alternative process for aerospace components, where the outstanding performance of high-velocity oxy-fuel (HVOF) coatings (e.g., carbide cermets-W, $\mathrm{Cr}$-in metallic matrix) was demonstrated (Ref 26). Although research on laser technologies as alternatives to hard chromium plating has been going on for a decade, further investigation is still needed (Ref 25, 27, 28). Recently, laser cladding, which relies on laser to melt a powder onto a substrate to form a coating (Ref 29), has been used to replace electrodeposition of $\mathrm{WC}-\mathrm{Co}$ (Ref 30).

As environmental aspects are becoming increasingly important in the evaluation of industrial processes, comprehensive environmental assessment methodologies have been developed in parallel. Life cycle assessment (LCA) is commonly used to identify and compare the impact of different processes on human health and the environment (Ref 31). LCA methodology has been applied since 2006 to compare the environmental impacts of various thermal spraying techniques used as alternative dry processes to replace electrodeposition (Ref 32-34). First LCA studies on laser processes are even more recent. A comparative study (to be published) carried out at LERMPS (Belfort, France) shows that laser pretreatments (texturing and ablation) have no significant environmental impact, unlike traditional surface preparation methods (degreasing and grit blasting). Laser cladding and in situ laser remelting after plasma spraying were also demonstrated to be clean technologies (Ref 35, 36). The reduced environmental footprint of laser processes highlights their potential to become the "best available technology" in the dry deposition field. Next sections will describe the laser interaction with matter and present specific laser applications for the field of thermal spray technologies.

\section{Laser Interaction with Matter}

Lasers can produce an intense monochromatic beam of coherent electromagnetic radiation of any frequency (visible, infrared (IR), ultraviolet (UV), x-ray, etc.), whose amplitude can be continuous (continuous wave mode, $\mathrm{CW}$ ) or pulsed (pulsed wave mode, PW) with respect to time. CW lasers cover the spectral range from 365 to $1000 \mathrm{~nm}$ with output powers greater than $100 \mathrm{~W}$ (Ref 37, 38). Pulsed lasers cover a larger part of the electromagnetic spectrum and are advantageous for some applications as higher peak powers can be achieved: the shorter the pulse, the higher the output peak power for the same average power ( $\operatorname{Ref} 37,39,40)$.

Laser energy is absorbed following two complementary mechanisms, namely the photonic absorption and the 
inverse Bremsstrahlung absorption (Ref 41), which result in the excitation of electrons in matter. The relaxation of these electrons follows three different mechanisms depending on the electric properties of the irradiated material. Excited electrons are trapped in the case of insulating materials; heat radiation occurs in the case of semiconductor materials; and a quantum of vibration energy (phonon) is emitted in the case of conducting materials. In the later case, the relaxation phenomenon induces either thermal effects (vaporization occurs due to the local increasing of temperature) or nonthermal effects such as photoablation (Ref 42).

The laser-matter interaction depends on the material properties (e.g., chemical and physical properties, surface roughness), the laser radiation characteristics (e.g., wavelength, energy density, laser fluence, and duration of irradiation), and the surrounding atmosphere (e.g., pressure and temperature) (Ref 43, 44). For instance, different effects on irradiated matter are observed at different laser fluence thresholds ( $\operatorname{Ref} 45,46)$. A number of laser treatments are thus available depending on the type of material to be irradiated and the laser beam characteristics (Ref 47). Figure 1 shows a selection of laser machining treatments and their effects on metallic substrates as a function of the power density and interaction time (Ref 43).

In the particular case of laser ablation of metals (i.e., materials with free electrons), the laser wavelength and the pulse time duration were pointed out as the key parameters of the ablation mechanism (Ref 48). Principally, the ablation results either from the thermal effect due to IR low-energy photons or from the photonic effect due to UV high-energy photons. Laser surface cleaning and laser ablation imply the removal of contaminants (oxides, oils, etc.) or matter, respectively, by a transition from their solid state to dispersed phases. Usually,



Fig. 1 Overview of laser machining processes and their interaction with metallic substrates (Ref 43) evaporation takes place when the vapor pressure of the liquid phase exceeds the surrounding pressure (Ref 49). For high-thermal inputs, however, the solid-liquid and liquid-gas transitions are not clearly defined. In fact, these transitions can be achieved simultaneously by rapid heating of a solid to a temperature over its boiling point.

Considering low-energy photons, laser ablation of conductive materials results from three sequential effects (Ref 44), namely laser beam absorption, thermalization, and heat transfer. The former is caused by electrostatic interaction between the magnetic field caused by the radiation and the valence electrons of the material. Depending on the energy of the photons (i.e., the beam wavelength), the absorbed intensity varies with the depth following the Beer-Lambert relationship. Some of the parameters that significantly influence the radiation absorption are the skin depth, the surface temperature, the angle of incidence of the laser beam, and the substrate surface topography. Among those, the key parameter is the skin depth that is the depth at which the intensity amplitude decays by a factor of 0.37 (i.e., 1/e). The skin depth $(\delta)$ depends on the laser wavelength $\lambda(\mathrm{m})$ and the material extinction dimensionless coefficient $\kappa$ that is the imaginary part of the complex index of refraction $(n)$ (Ref 50) following the next equation:

$\delta=\frac{\lambda}{2 \pi \kappa}$

Table 1 displays values of the absorption characteristics $(\lambda=1.06 \mu \mathrm{m})$ for some metallic materials, under a normal incidence angle and an ideal surface (plane without roughness) (Ref 51).

The radiation absorption in the bulk is then converted into heat via different types of collisions (photon-electron, electron-electron, or electron-phonon). The thermalization process takes place when this heat input rises the energy of the valence electrons that start to vibrate. These collisions and vibrations quickly increase the temperature of a layer of thickness equal to the heat penetration depth $(d)$ :

$d=\sqrt{4 D t}$,

where $D$ is the material thermal diffusivity $\left(\mathrm{m}^{2} / \mathrm{s}\right)$ and $t$ is the diffusion time (s) (Ref 52).

Heat transfer is dominated by the heat conduction and thus, it is proportional to the temperature gradient. The short duration of laser pulses $\left(10^{-13}-10^{-10} \mathrm{~s}\right)$ during ablation prevent heat conduction into the substrate and therefore this treatment does not produce significant

Table 1 Absorption characteristics for some metallic materials for a normal incident 10 ns-pulsed radiation of wavelength $\lambda=1.06 \mu \mathrm{m}(\operatorname{Ref} 51)$

\begin{tabular}{lrrr}
\hline Material & $\boldsymbol{\kappa}$ & $\boldsymbol{\delta}, \mathbf{n m}$ & $\boldsymbol{d}, \boldsymbol{\mu m}$ \\
\hline $\mathrm{Al}$ & 10.62 & 7.95 & 1.43 \\
$\mathrm{Ti}$ & 5.99 & 14.13 & 0.63 \\
$\mathrm{Fe}$ & 4.52 & 18.66 & 0.99 \\
$\mathrm{Cu}$ & 6.07 & 13.89 & 0.21 \\
\hline
\end{tabular}

. 

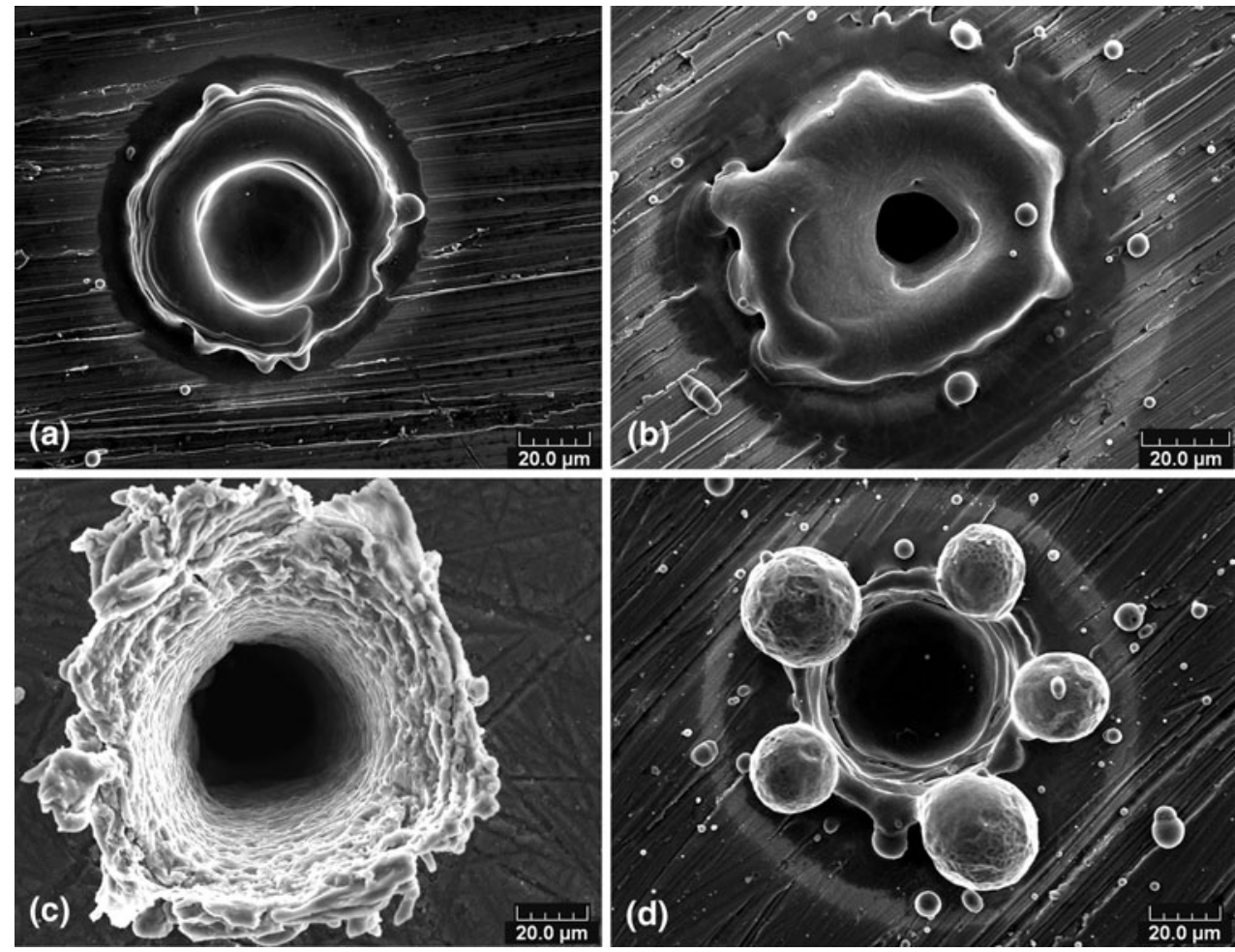

Fig. 2 Example of recast material morphologies surrounding textured cavities due to inadequate selection of laser texturing parameters (1.06 $\mu \mathrm{m}, 160 \mathrm{~ns}, 20 \mathrm{kHz}, 12 \mathrm{~W}, 67$ pulses): (a) Inconel 718, (b) steel C35E, (c) Mg AZ91, and (d) Ti6Al4V

heat-affected zones in the bulk material (Ref 53). This causes an extremely fast increase of thermal energy in the skin depth, so that melting and vaporization of the material take place, followed by ionization and formation of a dense plasma (Ref 54). The rapid expansion of this plasma is usually described by the equations of continuity, momentum, and energy conservation (Ref 55). This expansion and the associated pressure drop generate uniaxial compression stresses in the direction of the shock wave from which tensile stresses parallel to the surface are generated (Ref 56).

Laser texturing is a treatment in which the energy of the laser beam is concentrated in a small spot. The laser beam interaction with matter, in this case, can be described by a cyclic process determined by the pulse frequency. The cycle starts when the laser impact induces the melting of a thin layer of material which is subsequently vaporized (Ref 57). The vapor plume formed induces a recoil pressure on the molten material, which is expelled toward the edges of the impact (Ref 58). Most of the melted material returns to its original place after the pulse, forming a melt pool (Ref 59), however, some material can be expelled and form a ring of recast material surrounding the textured cavities (Ref 60) (Fig. 2). It is important to clarify that the melt pools are only formed when IR ns-to-ms pulsed lasers are used; they do not form if UV or IR ultrashort pulsed lasers are used. It must also be highlighted that the amount of energy absorbed by the material depends on its thermal diffusivity and the laser beam pulse duration, which in turn depends on the laser frequency and energy (Ref 52). A low-thermal diffusivity means that the energy is absorbed by the surface of the material, resulting in surface melting and vaporization, while the bulk remains cold and therefore unaffected (Ref 60).

\section{Selected Cases of Integrated Laser Surface Treatments}

\subsection{Laser-Integrated Pretreatments}

Coating adhesion is the most important in-service coating property, which in most cases is achieved by the mechanical anchoring of the coating onto a roughened substrate surface. Therefore, substrate preparation is required to provide suitable surface conditions for coating anchoring. The most commonly used pretreatment before thermal spraying consists of surface degreasing using solvents followed by grit blasting with $\alpha$-alumina white corundum. However, this two-step method is time consuming, not environmentally friendly and has other potential drawbacks, as previously described.

Alternative pretreatments have been studied by several research groups. Denoirjean et al. (Ref 61, 62) demonstrated that ceramic $\left(\mathrm{Al}_{2} \mathrm{O}_{3}\right)$ coatings deposited onto lowcarbon steel substrates previously oxidized up to $300{ }^{\circ} \mathrm{C}$ under a $\mathrm{CO}_{2}$ atmosphere significantly improved the coating tensile adhesion. These improvements are related to the growth of a Wüstite $(\mathrm{FeO})$ layer on top of the metallic 
substrates during the oxidizing step, which leads to epitaxial solidification of the alumina lamellae. However, this approach cannot easily be applied for industrial process due to the relatively high temperature required, which can lead to metallurgical modifications of the metallic substrates. Water jet, carbonic gas, and laser were also studied as potential alternative surface preparation methods (Ref 52, 63). However, laser processes are the only ones that can be applied to water-sensitive materials. Among laser pretreatments, ablation of the substrate (a few milliseconds before it is impacted by sprayed particles) proved to achieve similar tensile adhesion values to those obtained after conventional surface preparation (Ref 64).

3.1.1 Ablation: Case Study of Aluminum and Titanium Alloys. The main parameters influencing the ablation are the pulse duration, the beam energy, and the surface absorptivity for a given wavelength. For any given material, the laser-matter interaction leads to different local effects at the outer surface (Ref 64-66), like the generation of craters where chemical inclusions or geometric defects (scratches, etc.) are located on the surface. For energy



Fig. 3 Effect of laser fluence on the average roughness of polished Ti6Al4V (Ref 65) densities ranging between the ablation threshold (which permits to clean the surface from contaminants, oils, dust, etc.) and the surface melting point, the crater density increases with the energy density, resulting in an increased average surface roughness. For higher energy densities, a smoothing effect takes place due to the flow of molten matter toward the periphery of the craters (Fig. 3). Another possible effect consists in the growth of an oxide layer on the ablated metallic surface, as a result of the increased surface temperature after irradiation (Fig. 4). The thickness of this oxide layer depends on the laser parameters and material, and it can be as thin as a few nanometers (Ref 66).

Ablating the substrate surface just before the particle impingements also leads to desorption of contaminants and as a result to lamellae with lower splashing (Fig. 5) (Ref 67). This allows better particles/substrate contact which results in improved interfacial adhesion.

The adhesion mechanism is ruled by different phenomena depending on the surface pretreatment. The surface roughness induced after degreasing and grit blasting (conventional pretreatment) promotes the mechanical anchoring of molten particles (Ref 68), whereas it is the low roughness $(<1 \mu \mathrm{m})$ and presence of an oxide layer (depending on the type of material) that enable the physico-chemical bonding between both materials after laser ablation (Fig. 6) (Ref 67, 69).

In some cases, like the ablation of aluminum AISI 2017, no oxygen can be detected at the interface although a native oxide layer was clearly observed on the as-received substrates (Fig. 7). Interactions between particles and substrate can be promoted in order to improve the interfacial adhesion as shown in Table 2, whichever the spraying process or material type.

3.1.2 Preheating: Case Study of Aluminum and Titanium Alloys. The quality of thermally sprayed coatings is strongly dependent on the flattening dynamics of the impinging particles that build-up on the deposit. This in turn depends on many factors such as the substrate surface (type of material, temperature, surface topography, and presence of contaminants) and the characteristics of the impinging sprayed particles (temperature, velocity, diameter, oxidation, etc.) (Ref 70). Substrate temperature
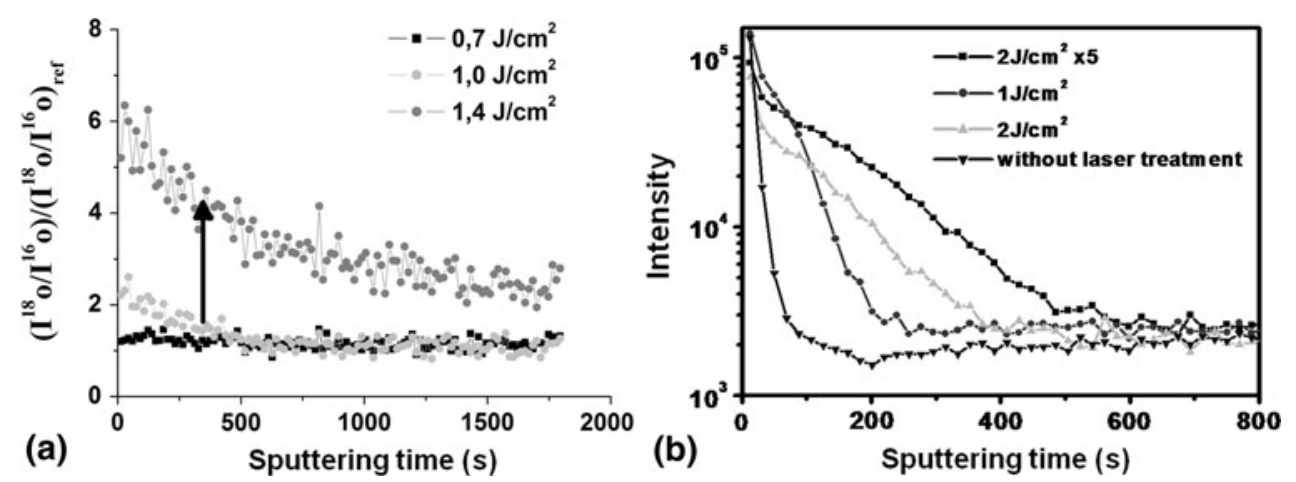

Fig. 4 Depth profile of the oxygen content acquired by SIMS on (a) pure aluminum and (b) titanium alloy laser-treated surfaces at different laser fluences and pulse number (Ref 65,66 ) 




Fig. 5 Influence of initial Ti6Al4V surface condition (polished, oxidized, and polluted by glycerol) and surface treatment (as-machined or ablated) on copper splat morphologies (Ref 67)

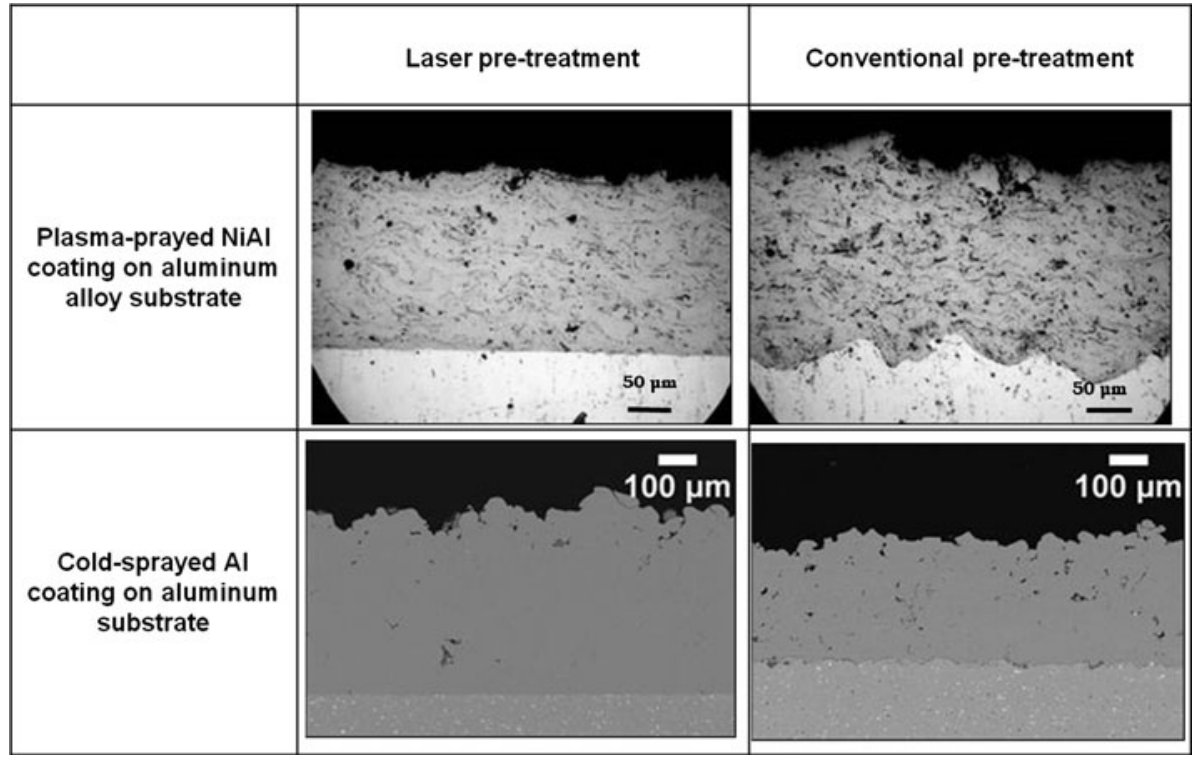

Fig. 6 Cross section $\mathrm{OM}$ observations of coating sprayed on laser pretreated substrates and conventionally pretreated substrates (Ref 67, 69)

strongly influences the coating microstructure due to its effect on particles/substrate interactions, and it is also related to the thermal desorption of surface adsorbates/ condensates resulting in a better coating/substrate adhesion and a better cohesion of the coating (Ref 71-73). However, temperature must be controlled to avoid macroscopic residual stresses during the cooling process. Preheating of the substrates can be done in a furnace or in situ using the thermal spray gun (plasma, flame, etc.), but intensive oxidation of the surface and distortions of the material can occur due to the large area of the jet and the treatment duration. This is why laser technology is a promising alternative process for this application. Indeed, using optical fibers, a local simultaneous treatment can be implemented to limit the heated area to the one impinged by plasma-sprayed particles, thus preventing undesired surface modifications in the surrounding areas (Fig. 8) (Ref 74). It has been proved that the local oxidation after laser preheating (if any) is also minimized to a thickness of few nanometers, which does not affect the coating adhesion (Ref 75, 76).

Different coating properties can be optimized selecting adequate processing parameters (laser beam energy, wavelength, continuous/pulsed, etc.). For instance, 

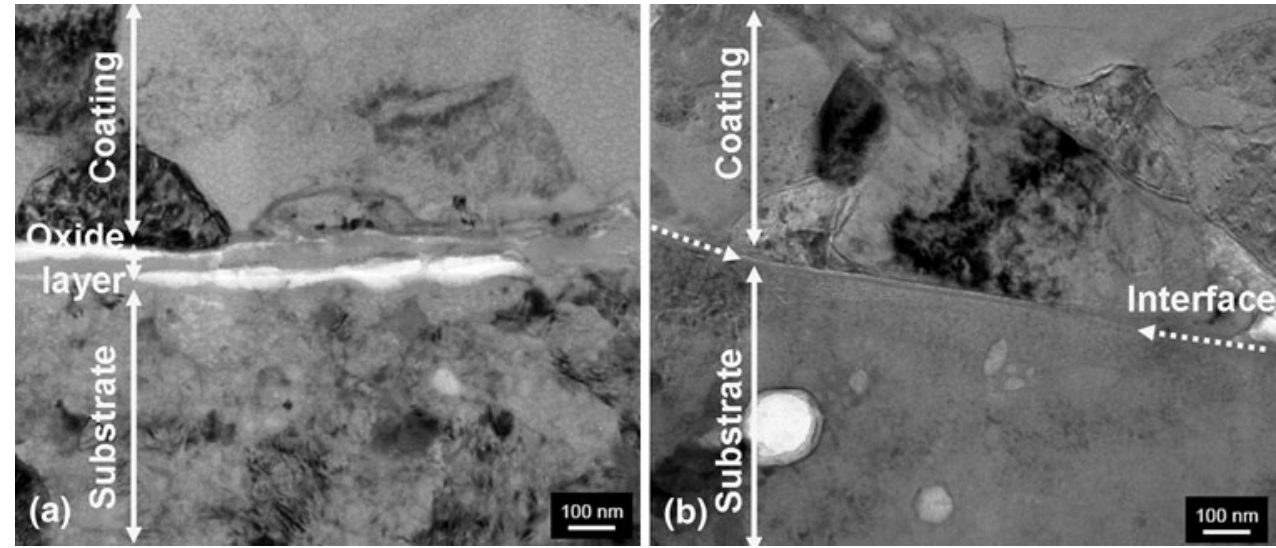

Fig. 7 TEM bright field images of cold-sprayed Al powder on: (a) as-received and (b) laser pretreated $\left(2.2 \mathrm{~J} / \mathrm{cm}^{2}, 150 \mathrm{~Hz}\right) \mathrm{AISI} 2017$ substrates (Ref 69)

Table 2 Average adhesion values and standard deviation for several coatings sprayed on various substrates implementing different spray technology with different laser energy densities

\begin{tabular}{|c|c|c|c|c|}
\hline \multirow[b]{2}{*}{ Spraying technique } & \multicolumn{2}{|c|}{ Materials $^{\mathbf{a}}$} & \multirow[b]{2}{*}{ Laser fluence, $\mathrm{J} / \mathrm{cm}^{2}$} & \multirow[b]{2}{*}{ Tensile adhesion', MPa } \\
\hline & Substrate & Coating & & \\
\hline \multirow[t]{8}{*}{ APS } & Aluminum AISI 2017 & $\mathrm{Cu}$ & 1.25 & $31 \pm 4$ \\
\hline & & $\mathrm{Ni}-20 \mathrm{Cr}$ & 0.75 & $40 \pm 4$ \\
\hline & & $\mathrm{Al}_{2} \mathrm{O}_{3}-13 \mathrm{TiO}_{2}$ & 1.50 & $34 \pm 6$ \\
\hline & & $\mathrm{Ni}-5 \mathrm{Al}$ & 1.00 & $48 \pm 6$ \\
\hline & Ti6Al4V & $\mathrm{Cu}$ & 0.75 & $58 \pm 4$ \\
\hline & & $\mathrm{Ni}-20 \mathrm{Cr}$ & 0.75 & $58 \pm 6$ \\
\hline & & $\mathrm{Al}_{2} \mathrm{O}_{3}-13 \mathrm{TiO}_{2}$ & 1.00 & $78 \pm 9$ \\
\hline & & $\mathrm{Ni}-5 \mathrm{Al}$ & 1.50 & $31 \pm 2$ \\
\hline \multirow[t]{3}{*}{ TWEA } & Aluminum AISI 7075 & $\mathrm{Al}-5 \mathrm{Mg}$ & 1.50 & 35 \\
\hline & & 1015 & 1.75 & 48 \\
\hline & $\mathrm{Fe}-10 \mathrm{Mn}-5 \mathrm{Cr}$ & $\mathrm{Cu}-6 \mathrm{Sn}$ & 2.00 & 31 \\
\hline HVOF & Steel AISI 4340 & WC-17Co & 1.25 & $>90$ \\
\hline \multicolumn{5}{|c|}{ 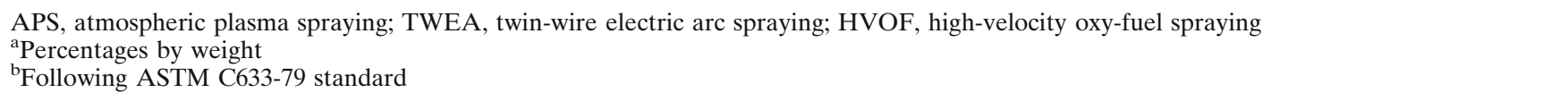 } \\
\hline
\end{tabular}

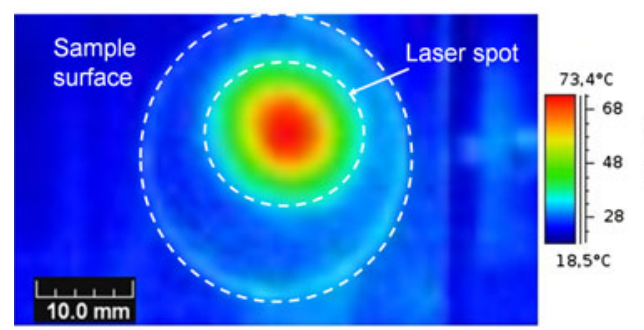

(a)

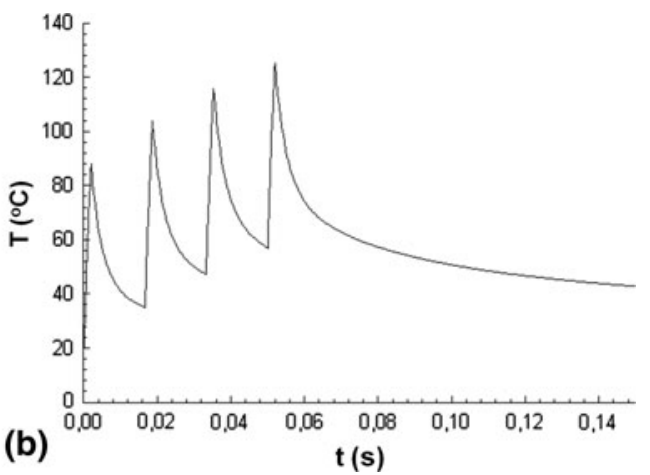

Fig. 8 (a) Thermal image of the reduced Nd:YAG laser spot after 25 pulses of $5 \mathrm{~ms}$ at $40 \mathrm{~Hz}$, fluence of $5.1 \mathrm{~J} / \mathrm{cm}^{2}$; and (b) temperature variation during Nd:YAG laser treatment consisting of four pulses of $2 \mathrm{~ms}$ at $60 \mathrm{~Hz}$, fluence of $29.7 \mathrm{~J} / \mathrm{cm}^{2}(\mathrm{Ref} 74)$

porosity, hardness, and adhesion can be significantly modified by implementing a laser heating pretreatment (Fig. 9) (Ref 64, 77-79). Further improvement of the adhesion was achieved by combining laser ablation process and local laser heating, particularly in the case of cold spray (Fig. 10) (Ref 80). 

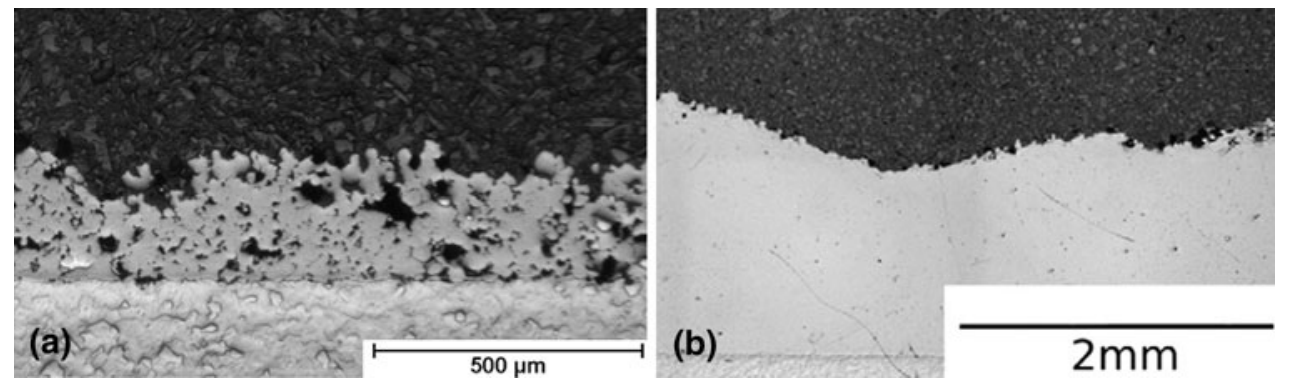

Fig. 9 Cross section OM observations of titanium coating cold sprayed after laser pretreatment at (a) 450 and (b) $550{ }^{\circ} \mathrm{C}(\mathrm{Ref} 77)$

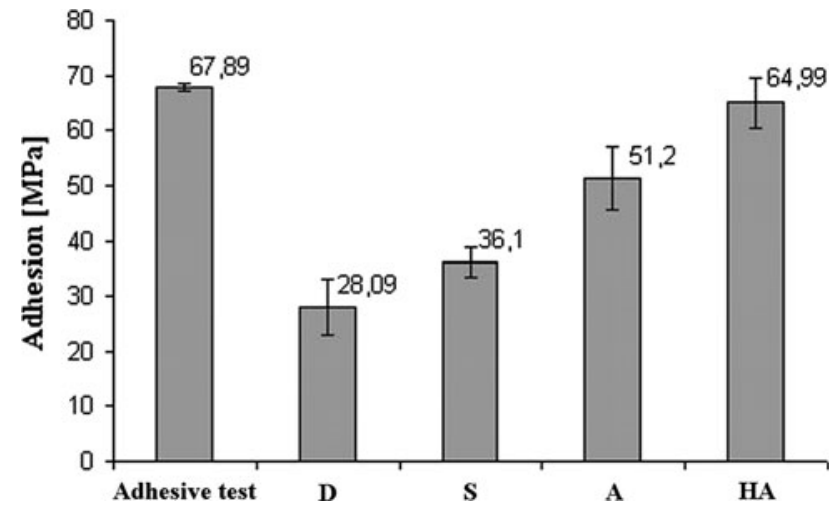

Fig. 10 Adhesion values for cold-sprayed aluminum coatings on AISI 2017 surfaces: degreased (D); sandblasted (S); laser ablated $\left(2.3 \times 10^{8} \mathrm{~W} / \mathrm{cm}^{2}\right) \quad(\mathrm{A}) ;$ laser heated $\left(1.5 \times 10^{4} \mathrm{~W} / \mathrm{cm}^{2} \approx\right.$ $\left.131^{\circ} \mathrm{C}\right)$ and ablated $\left(2.3 \times 10^{8} \mathrm{~W} / \mathrm{cm}^{2}\right)(\mathrm{HA})($ Ref 80$)$

\subsection{Laser-Integrated Hybrid Treatments: Simultaneous Remelting of Metallic Ni-Based Layers and Ceramic Alloy $\left(\mathrm{ZrO}_{2}\right)$}

Hybrid plasma laser deposition manufacturing (PLDM), also called laser-plasma hybrid spraying system (LPHS) or in situ laser remelting, is a new technique that combines a thermal spray gun and a laser to improve the coating properties. This technique was used combining a lowpressure plasma spray with a high-power $\mathrm{CW} \mathrm{CO}_{2}$ laser irradiation, allowing the production of high-performance tribo-materials with good adhesion and scarce microporosity (Ref 81,82 ). In ceramic materials (i.e., materials without free electrons) the far-IR radiation is the better absorbed and therefore, the $\mathrm{CO}_{2}$ laser seems the most suitable choice to treat them. However, $\mathrm{CO}_{2}$ lasers are expensive, require complicate maintenance procedures and its radiation cannot be conducted by optical fibers, contrary to the Nd:YAG laser radiation (near-IR radiation). Therefore, YAG and diode lasers are preferred for industrial applications. Hybrid spraying using a YAG fiber laser combined with plasma spraying has often been applied to ceramic layers such as thermal barrier coatings (TBCs), in order to improve some of their properties. For instance, thermal diffusivity, thermal shock resistance, hardness, high-temperature erosion resistance, and hot oxidation resistance in hot sandy environments were improved by the formation of denser coatings (Ref 82-85). The bonding strength between particles was greatly increased and the interconnected porosity and cracks were prevented (Ref 86). Good interface between the coating and the substrate, and smooth coating surfaces were also obtained (Ref 85). Although similar results were found using diode lasers, the presence of cracks and delamination due to rapid solidification following the laser treatment, presented a risk of rapid degradation by thermal fatigue (Ref 87).

Since metals reflect most of the laser energy, the diode laser $(\lambda=0.848 \mu \mathrm{m})$ is a better choice to treat metallic alloys than the $\mathrm{CO}_{2}$ laser $(\lambda=10.6 \mu \mathrm{m})$ or the $\mathrm{Nd}$ :YAG laser $(\lambda=1.06 \mu \mathrm{m})$. Ni-based layers resulting from in situ laser remelting using a diode laser present dendritic and dense structures (Fig. 11) with enhanced mechanical properties compared with those of lamellar structures resulting from thermal spray (Ref 88,89 ). The coating adhesion is also improved as it is metallurgically bonded to the substrate. It presents finer structures without modifying the phase content of the layer (Ref 36). In situ laser remelting reduces also the cooling stresses due to the low level of laser energy required. In addition, this hybrid technique improves the wear and corrosion resistance of the coatings. For instance, the results from the wear tests carried out on NiCrBSi coatings showed that the adhesive wear mechanism was caused by oxidation in the case of the laser remelted hybrid layer and by surface fatigue for the as-sprayed layer (Ref 88). Corrosion potentials of as-sprayed coatings were found to be approximately $150 \mathrm{mV}$ lower than the one of remelted coatings (Ref 90). Different corrosion mechanisms take place in both coatings, even if the feedstock material is the same. The lower corrosion resistance observed in as-sprayed coatings is caused by a greater porosity and higher concentration of defects, which allow the electrolyte to reach the substrate surface. This accelerates the formation of a galvanic couple between coating and substrate, accelerating the dissolution rate of the substrate. Iron oxides produced from the substrate corrosion travel through the defects toward the outer surface, modifying the composition of the layer. On the contrary, the substrate surface of in situ remelted samples is not reached, because of a higher density. As an example, Table 3 shows some of the properties of metallic alloy coatings treated by laser remelting hybrid technique. 


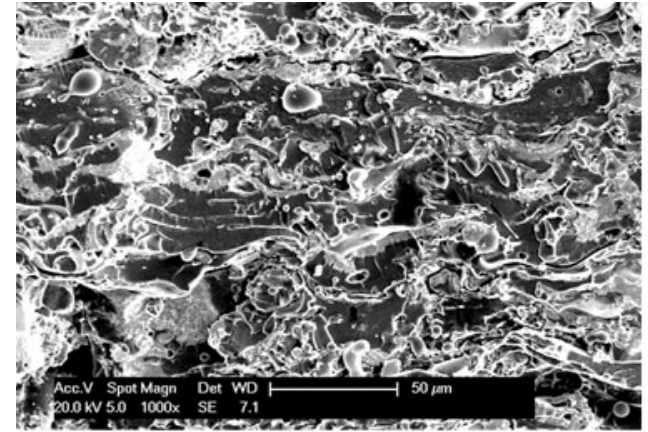

(a)

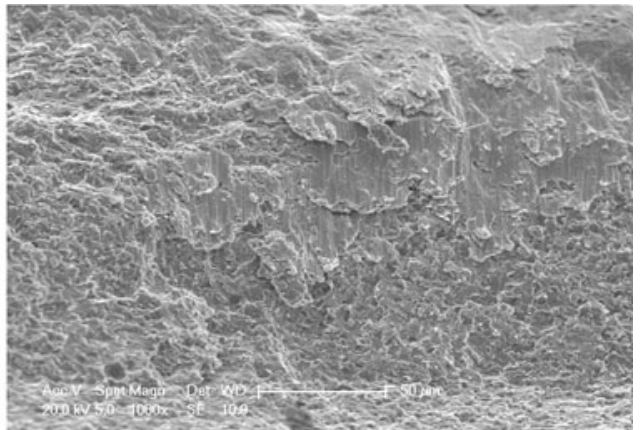

(b)

Fig. 11 Fracture SEM observations of: (a) as-sprayed and (b) remelted NiCrBSi coating

Table 3 Main characteristics of NiCrBSi alloy coatings coated with different technologies

\begin{tabular}{|c|c|c|c|}
\hline Coating property & APS & In situ laser remelting & Ref \\
\hline Microstructure & Lamellar & Dendritic & 36 \\
\hline Adhesion mechanism & Mechanical anchorage & Metallurgical bond & 36 \\
\hline Porosity, \% & $3.4 \pm 0.3$ & 0 & 88 \\
\hline Microhardness, $\mathrm{GPa}^{\mathrm{a}}$ & $6.23 \pm 0.88$ & $10.08 \pm 0.82$ & 89 \\
\hline Young's modulus, $\mathrm{GPa}^{\mathrm{a}}$ & $204.56 \pm 24.18$ & $232.04 \pm 15.08$ & 89 \\
\hline Wear rate $\left(\times 10^{-8}\right), \mathrm{mm}^{3} / \mathrm{m} \mathrm{N}^{\mathrm{b}}$ & $2.1 \pm 0.2$ & $1.1 \pm 0.1$ & 88 \\
\hline Corrosion potential in $\mathrm{NaCl}, \mathrm{mV}$ vs. $\mathrm{SCE}^{\mathrm{c}}$ & -415 & -270 & 90 \\
\hline Corrosion current density in $\mathrm{NaCl}, \mathrm{A} / \mathrm{cm}^{2}$ & $8.06 \times 10^{-5}$ & $7.19 \times 10^{-8}$ & 90 \\
\hline
\end{tabular}

\section{Selected Cases of Nonintegrated Laser Surface Treatments}

\subsection{Laser Pretreatments: Surface Texturing of Aluminum Alloy Substrates}

A number of techniques for surface texturing, such as vibrorolling, abrasive machining, reactive ion etching, abrasive jet machining lithography, and anisotropic etching have been developed over the last decades (Ref 91). Although laser surface texturing (LST) has been used for over 15 years in the magnetic storage industry (Ref 92, 93) and for tribology and sealing applications (Ref 94-97), it is a novel pretreatment process for thermal spray applications. The potential of this technique lies in the wide range of materials that can be treated (including ductile materials), the reduction of the heat-affected area and the low deformations induced within thin substrates. These characteristics make LST pretreatments suitable to produce surfaces free of grit-particle inclusions, what directly improves the quality of thermal-sprayed coatings.

LST is a laser engraving technique which involves the construction of geometric patterns, as for example shallow spot-shape cavities at quasi-regular intervals or crossed thin grooves (Fig. 12) (Ref 98). The desired pattern can be obtained either by scanning the laser along a defined path (maintaining the focal distance and modulating the pulses to vaporize the material at desired locations) or by irradiating the substrate through a mask. Although texturing can be done using a single high-energy pulse, it was demonstrated that higher quality textures can be achieved using multiple low-energy laser pulses (Ref 57). The quality of texturing depends on the characteristics of the laser beam (e.g., wavelength, pulse duration, spot diameter, pulse frequency, and defocusing distance), the scanner characteristics (e.g., speed of scanning and resolution), the physical characteristics of the substrate (e.g., absorption coefficient, thermal conductivity, surface condition, and vaporization temperature), and other characteristics related to the environment ( $\operatorname{Ref} 60,99,100)$. Therefore, it can be said that the quality of the textures highly depends on the laser-matter interaction. An inadequate set of process parameters for a specific material can cause the melting of the surrounding areas of the textured patterns, followed by rapid resolidification and thermal cracking. It can also result in undesired vapor blast ejection of melted material (spatter) throughout the entire surface (Ref 59, 101). In addition, processing difficulties can be inherent to the material. For instance, aluminum laser processing is complex due to its high reflectivity to light, its highthermal conductivity and the high-melting and boiling point of the alumina pacifying layer (formed by selfextinguishing oxidation reaction) (Ref 102).

Research has been conducted to determine the effects of diverse laser parameters on a number of texture features (including cavity dimensions, amount of recast 

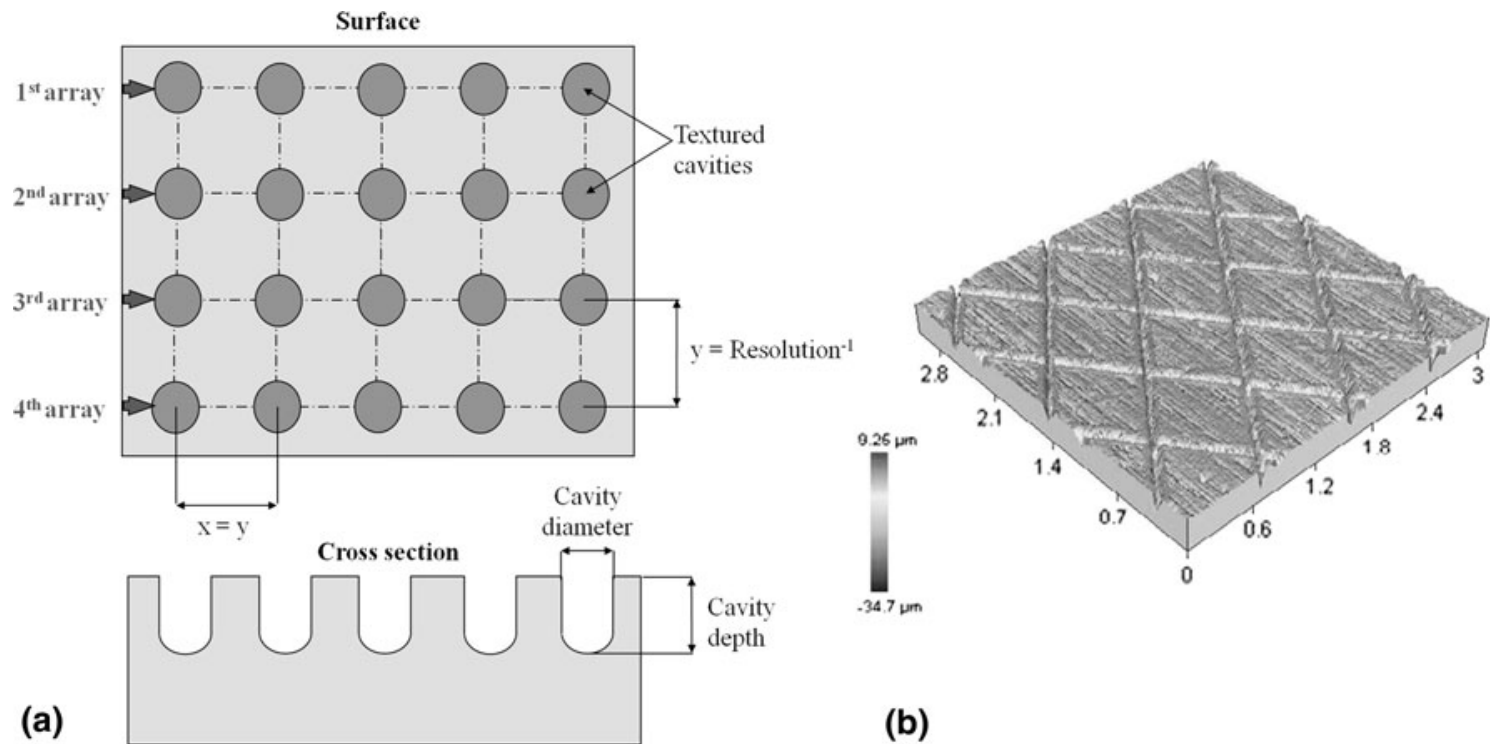

(b)

Fig. 12 Examples of laser surface textures: shallow spot-shape cavities and crossed thin grooves (Ref 98)
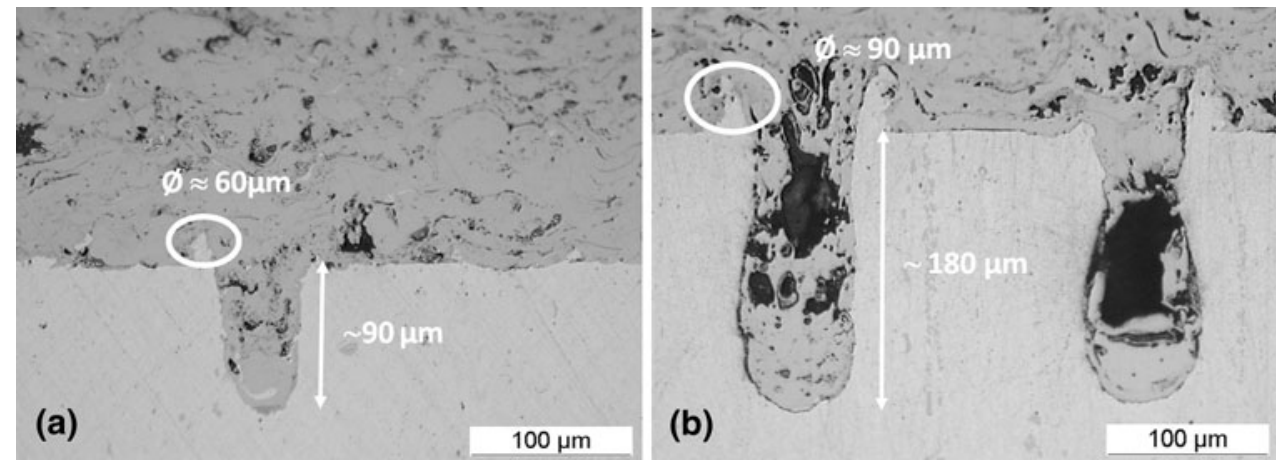

Fig. 13 OM cross section micrograph of plasma-sprayed AMDRY $956(\mathrm{Ni}-\mathrm{Al})$ powder (45 $\mu$ m particle average size) onto aluminum AISI 2017 substrates textured at different conditions: (a) $10 \mathrm{~W}, 40 \mathrm{kHz}, 32$ pulses/cavity, defocusing distance 0 and (b) $17.3 \mathrm{~W}, 20 \mathrm{kHz}$, 48 pulses/cavity, defocusing distance -1 (Ref 111)

material, roughness, etc.) for different materials, such as stainless steel (Ref 103-106), nickel (Ref 106), titanium alloys (Ref 105-109), and aluminum alloys (Ref 102, 105, 110-112). For aluminum alloy AISI 2017, the average depth of textured cavities was found to increase with increasing number of pulses per cavity and decreasing scan velocities; the cavities diameter and the volume of recast material surrounding the textured cavities was shown to increase with increasing laser power and defocusing distance (Ref 112). Cavities diameters tend to asymptotic values related to the beam spot size, whichever the treated material (Ref 108). The average roughness of textured aluminum alloy AA6056 substrates was shown to be mainly influenced by the frequency and scan velocity (Ref 105).

Suitable type of laser and adequate setting of processing parameters are necessary in order to tailor textures to the requirements of different applications (Ref 113). For instance, the adhesion of thermal-sprayed coatings on textured substrates is highly influenced by the pattern geometry and "additional" surface roughness (spatter and recast material), because both of them modify the surface contact area of the substrate (Ref 110). Particularly, the optimal cavities dimensions (i.e., diameter and depth) must be adapted depending on the sprayed powder average size $\left(d_{0.5}\right)$ to allow a good coating filling (Fig. 13). Adhesion of Ni-Al coatings on textured aluminum AISI 2017 was qualitatively assessed by interface indentation. Toughness values (and therefore adhesion) were found to slightly decrease with decreasing laser power (from 6.5 $\mathrm{MPa} \mathrm{m} \mathrm{m}^{-1 / 2}$ at $17.3 \mathrm{~W}$ to $4 \mathrm{MPa} \mathrm{m} \mathrm{m}^{-1 / 2}$ at $10 \mathrm{~W}$ ), but in all cases they remain higher than those reported for conventionally pretreated surfaces (3.5 $\mathrm{MPa} \mathrm{m^{-1/2 }}$ ) (Ref 110). Preliminary adhesion tests conducted following (ASTM C633-79 standard) showed the same trend (Ref 111).

\subsection{Laser Posttreatments: Densification of PEEK Coating on 304L Substrate}

Various coatings materials (metals, polymers, ceramics, and composites) have been studied to enhance the 
ultimate tribological behavior of substrate materials. The need to improve the mechanical and morphological properties of these coatings has driven the research on postprocessing of thermal spraying coatings (Ref 114-116). Laser postprocessing has been widely used over the last decade not only to densify thermal-sprayed coatings, but also to achieve structure refinement, to induce phase transformations and to enhance coating/substrate adhesion (Ref 117-119).

Metallic coatings such as aluminum, zinc, nickel, chromium, molybdenum, and their alloys and composites such as $\mathrm{NiCrBS}$ and $\mathrm{NiCrBCSi}(\mathrm{Fe})$, have been widely studied to improve the corrosion and wear resistance of substrates (Ref 120-126). Laser postspray treatment (Ref 120, 121, 123, 124) or furnace annealing (Ref 122, $125,126)$ are the most widely used techniques to induce structure refinement and densification of metallic coatings, and to improve their mechanical and metallurgical bonding.

Laser remelting of ceramic coatings and its effect on the microstructure, phase transformation and mechanical properties has been investigated by many authors (Ref 114-117, 127). For instance, postspray laser remelting of AT-13 $\left(\mathrm{Al}_{2} \mathrm{O}_{3}-13\right.$ wt.\% $\left.\mathrm{TiO}_{2}\right)$ and alumina $\left(\mathrm{Al}_{2} \mathrm{O}_{3}\right)$ thermal-sprayed coatings can be applied to transform as-sprayed metastable $\gamma-\mathrm{Al}_{2} \mathrm{O}_{3}$ phase into stable $\alpha-\mathrm{Al}_{2} \mathrm{O}_{3}$ phase (Ref 117, 118). Porosity and lamellae structures in as-sprayed coatings have been effectively eliminated after $\mathrm{Nd}$ :YAG and $\mathrm{CO}_{2}$ laser remelting, resulting in compact and homogenous microstructures (Ref 128-131). Excimer lasers have also been used for refining coating microstructure of plasma-sprayed alumina-titania (Ref 132).

Laser posttreatments have also been used for glazing of plasma-sprayed YSZ coatings (Ref 133), surface roughness reduction of zirconia coatings (Ref 134) and microstructure stabilization using Nd:YAG lasers. Recently, a diode laser was employed to increase the biocompatibility of plasma-sprayed titania-HA functionally graded coatings (Ref 135).

Organic polymeric coatings have gained increasing importance within the thermal spray research community. Organic materials are the most widely used to coat metallic substrates because they provide protection against corrosion and wear. Performance of coated metals depends on the metallic substrate, coating characteristics (polymer composition, integrity and thickness), interfacial adhesion, and environmental conditions. Among the most studied organics polymers for coating deposition are polytetrafluoroethylene (PTFE), polypyrrole (PPy), polyaniline (PANI), polyimide (PI), polyetheretherketone (PEEK), polyvinyl acetate (PVA), and polyvinyl chloride (PVC), since they can easily be processed and present adequate properties. Particularly, PEEK coatings are extensively used to enhance the in-service properties of various metallic substrates for different industrial applications.

PEEK is a semicrystalline thermoplastic material with excellent tribological properties, good chemical and wear resistance, good thermal stability, good mechanical properties, and low-frictional properties (Ref 136-141). These properties and the low levels of removable ionic species that are inherent to pure PEEK, make this polymer suitable for different applications in analytical, semiconductors, medical, and food industries. In addition, these properties are retained at temperatures as high as $315^{\circ} \mathrm{C}$ (Ref 142, 143), what increases its value as feedstock material for coating applications.

Polymer powder deposition can be done using several techniques such as electrophoresis, thermal spraying, and printing (Ref 68, 144-148). Flame spraying is the most widely used process to deposit polymeric powders onto metallic substrates, due to its reduced heating temperature and low-operating cost compared to other thermal spray processes (Ref 149-154). Unfortunately, as-sprayed organic polymers coatings present low-mechanical properties due to their high porosity and low adhesion to metallic substrates (Fig. 14). To avoid this, different postspraying heat treatments have been studied by several authors (Ref 14, 149, 155, 156).

Densification of polymeric coatings onto metallic substrates is conventionally performed using flame, oven, and microwave techniques (Ref 144, 145, 147). The viability of lasers for this application is still unclear due to the varying absorption coefficients of polymers for different laser wavelengths. Absorption occurs if the frequency of the incident photons corresponds to the frequency associated with the transition energy of irradiated molecules (Ref 14, 149, 155-158). Part of the absorbed energy is transformed into thermal energy, which leads to coating melting. The exceeding energy is partially absorbed (heating the substrate) and partially reflected by the metallic substrate/ polymer coating interface. Densification of polymers coatings on metallic substrates is usually caused by both transmitted and reflected laser beam radiation. Figure 15 shows the schematics of as-sprayed and laser posttreated coatings.

The advantages of laser densification over the conventional densification techniques (furnace) are the shorter treatment time and the fast response of the

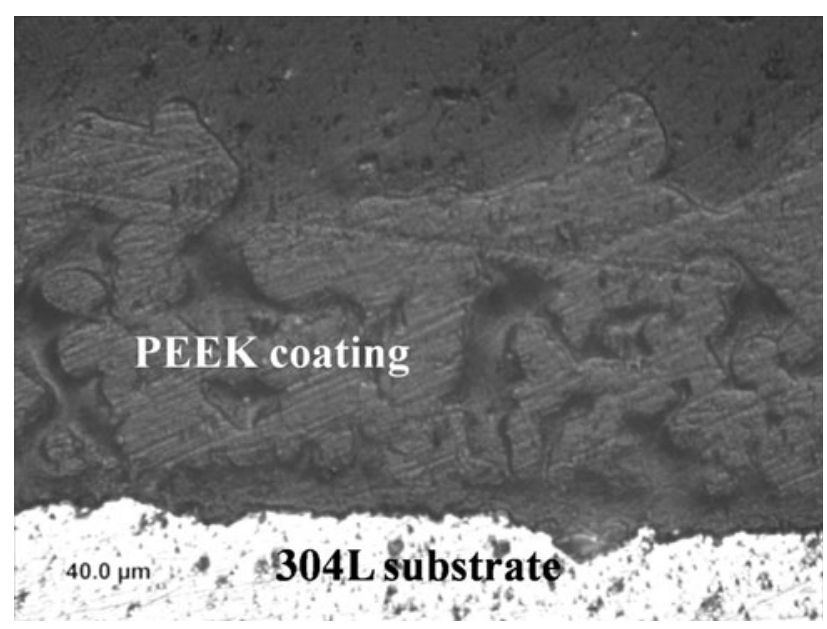

Fig. 14 Microstructure of as-sprayed PEEK coating onto stainless steel substrate 


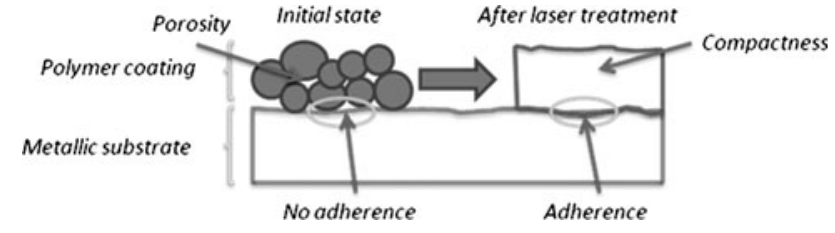

Fig. 15 Schematics of as-sprayed and laser posttreated coatings

polymer to the laser beam radiation. Specially, UV laser radiation can break chemical bonds and cause chemical reactions on the irradiated surface, owing to simultaneous photochemical and thermal effects. UV laser treatments proved to be more effective than IR lasers in preadhesion surface treatments of polymers (Ref 159,160$)$, due to chemical activation of the material particles with minor heat effect. There are different types of lasers in the domain between UV and IR to postprocess thermal spray coatings: diode laser (near IR, $\lambda=0.808$ and $0.940 \mu \mathrm{m}$ ), Nd:YAG laser (near IR, $\lambda=1.06 \mu \mathrm{m}$ ), excimer laser (UV, $\lambda=0.193 \mu \mathrm{m} \quad$ ArF, $0.248 \mu \mathrm{m} \quad \mathrm{KrF}, \quad 0.308 \mu \mathrm{m} \quad \mathrm{XeCl}$, $0.353 \mu \mathrm{m} \mathrm{XeF}$ ) and $\mathrm{CO}_{2}$ laser (mid-IR, $\lambda=10.64 \mu \mathrm{m}$ ). The choice of laser depends on the type of application and material to be irradiated.

Coating remelting and morphology modification require deep penetration of laser radiation, which is achieved by long laser treatments in CW mode, whereas coating smoothing or glazing is obtained by short laser treatments in pulsed mode. Current research in laser densification focuses on optimizing the main laser operating parameters of three types of lasers: Nd:YAG laser, $\mathrm{CO}_{2}$ laser, and diode laser. Studies on densification of polymers coatings (Ref $13,149,156)$ have shown that with $\mathrm{CO}_{2}$ laser, the incident laser beam is easily absorbed by polymers, whereas most of them are transparent at the wavelength of Nd:YAG laser. Diode laser beam radiation is less absorbed by most organic polymers, leading to a greater heating of the coating/substrate interface which results in improved adhesion.

For instance, PEEK response to different laser beam radiations depends on the type of laser used, which is due to PEEK's laser-dependant transmission factor: $50 \%$ for Nd:YAG laser, $10 \%$ for $\mathrm{CO}_{2}$ laser, and $80 \%$ for diode laser (Ref 13, 149). Figure 16 shows the microstructure of PEEK coatings after densification using these three types of lasers.

Densification posttreatment using Nd:YAG lasers with a reduced interaction time and a high-power density can be used to improve adhesion and compactness of PEEK coatings. Similar results (Fig. 16a) can be achieved at lower power densities by reducing the operating speed, while the energy per unit area remains relatively high $\left(\sim 21 \mathrm{~J} / \mathrm{mm}^{2}\right)$. The polymeric coating presents a vitreous structure, which indicate slight polymer overheating (phase transformation from crystalline to amorphous). Decreasing the treatment velocity (i.e., incrementing interaction time) excessively can result in sample overheating and coating degradation by polymer vaporization (Fig. 16b). Figure 16(c) shows the microstructure of a PEEK coating densified using a $\mathrm{CO}_{2}$ laser at a relatively low energy per unit area $\left(7.10 \mathrm{~J} / \mathrm{mm}^{2}\right)$. It can be seen that a good polymer melting was obtained due to the highabsorption coefficient of PEEK for this type of laser beam, yet the coating adhesion to the metallic substrate is not satisfactory (porosity remains at the interface). Similarly to what happens with the Nd:YAG laser, an inadequate set of laser parameters (e.g., slower operating speed and higher laser power, i.e., moderate laser energy per unit area: $19 \mathrm{~J} / \mathrm{mm}^{2}$ ) can lead to overheating of the coating which can result in surface degradation such as polymer vaporization and substantial reduction of thickness (Fig. 16d). It has to be said that coating densification using $\mathrm{CO}_{2}$ and $\mathrm{Nd}$ :YAG lasers requires the setting of a large defocusing distance, and consequently larger laser spot diameter, both correlated with moderate laser powers in order to avoid thermal degradation of the polymer. A considerable improvement of the PEEK coating (densitywise) can be noticed after densification by diode laser treatment (Fig. 16e) with no changes in polymer crystallinity. Finally, diode laser densification of PEEK coatings results in excellent adhesion due to better penetration of the laser beam radiation up to the interface. Once more, inadequate setting of laser operating parameters, such as moderate operating speeds and high-laser energies $(71.2 \mathrm{~J} /$ $\mathrm{mm}^{2}$ ), fails to fully densify PEEK coatings, and pores can still be observed (Fig. 16f). It must be highlighted that thermal degradation does not occur under these conditions, but polymer melting is incomplete. A relatively low-operating speed during diode and Nd:YAG laser processing is needed, in order to obtain dense polymer coatings with no change in crystallinity using a single pass of laser beam. When it comes to $\mathrm{CO}_{2}$ laser, three times higher operating speed must be used to obtain the same results.

\section{Summary}

The implementation of laser treatments before, during, and after the thermal spray process allows for enhanced coating properties, which can be obtained using new degrees of freedom in the process parameters control. Recent research developments in that field and their potential benefits for the thermal spray industry were reviewed in this article, and several laser case studies were presented in further detail. Laser texturing, for instance, is a promising substrate pretreatment technique aiming to improve coating adhesion by mechanical anchoring and chemical bonding. Integrated (hybrid) laser/plasma spray techniques permit to increase coating/substrate adhesion, to reduce coating residual stresses, to improve coating cohesion, and to modify the microstructure. Coating densification can also be achieved using laser posttreatments. It must be highlighted that in all cases, the characteristics of the laser radiation (wavelength, energy density, pulse duration, etc.) must be optimized depending on each material and application. Lasers potential relies on an exclusive combination of processing advantages, like the wide range of materials that can be treated 



Fig. 16 Microstructure of PEEK coating after densification using a Nd:YAG laser: (a) good densification; (b) inadequate input parameters; $\mathrm{CO}_{2}$ laser: (c) good densification; (d) inadequate input parameters; diode laser: (e) good densification; (f) inadequate input parameters (Ref 149) (Note: all micrographs were taken at the same optical magnification 500×)

(including water-sensitive and embrittlement-prone materials), the reduced heat-affected area and the low deformation of thin substrates. Other benefits of laser technologies are their low-processing times, high flexibility, precision and low-environmental impact, which could encourage industrial coating manufacturers to implement them at different stages of the thermal spray processes.

\section{Acknowledgments}

The research works presented as study cases in this review were supported by Franche-Comté, Alsace and Bourgogne French regions, CAPM (Communauté d'Agglomération du Pays de Montbéliard), ADEME (Agence de l'Environnement et de la Maîtrise de l'Energie), and Education French Ministry.

\section{References}

1. T.J. Steeper, A.J. Rotolico, J.E. Nerz, W.L. Riggs, D.J. Varacalle, and G.C. Wilson, Optimizing Plasma Spraying Alumina-Titania Coatings Using Statistical Methods, Thermal Spray Coatings: Research, Design and Applications, C.C. Berndt and T.F. Bernecki, Ed., ASM International, Anaheim, CA, 1993, p 3748

2. R.B. Heimann, Plasma-Spray Coating: Principles and Applications, 2nd ed., Wiley-VCH, Weinheim, 2008

3. X.P. Jiang, X.Y. Wang, J.X. Li, D.Y. Li, C.-S. Man, M.J. Shepard, and T. Zhai, Enhancement of Fatigue and Corrosion Properties of Pure Ti by Sandblasting, Mater. Sci. Eng. A, 2006, 429(1-2), p 30-35

4. M. Multigner, E. Frutos, J.L. González-Carrasco, J.A. Jiménez, P. Marín, and J. Ibáñez, Influence of the Sandblasting on the Subsurface Microstructure of 316LVM Stainless Steel: Implications on the Magnetic and Mechanical Properties, Mater. Sci. Eng. C, 2009, 29(4), p 1357-1360

5. C. Leinenbach and D. Eifler, Fatigue and Cyclic Deformation Behaviour of Surface-Modified Titanium Alloys in Simulated Physiological Media, Biomaterials, 2006, 27(8), p 1200-1208 
6. M. Multigner, E. Frutos, C.L. Mera, J. Chao, and J.L. GonzálezCarrasco, Interrogations on the Sub-Surface Strain Hardening of Grit Blasted Ti-6Al-4V Alloy, Surf. Coat. Technol., 2009, 203(14), p 2036-2040

7. E. Petavratzi, S. Kingman, and I. Lowndes, Particulates from Mining Operations: A Review of Sources, Effects and Regulations, Miner. Eng., 2005, 18(12), p 1183-1199

8. A. Chillman, M. Ramulu, and M. Hashish, Water Jet and WaterAir Jet Surface Processing of a Titanium Alloy: A Parametric Evaluation, J. Manuf. Sci. Eng., 2010, 132(1), 011012 (10 pp)

9. E. Uhlmann and A. El Mernissi, Pre-treatment by Dry Ice Blasting for Adhesive Bonding, Prod. Eng., 2008, 2(2), p 133-138

10. C. Coddet, G. Montavon, S. Ayrault-Costil, O. Freneaux, F. Rigolet, G. Barbezat, F. Folio, A. Diard, and P. Wazen, Surface Preparation and Thermal Spray in a Single Step: The PROTAL Process-Example of Application for an Aluminum-Base Substrate, J. Therm. Spray Technol., 1999, 8(2), p 235-242

11. "Laser Material Processing", Centro Laser of Valenzano (BA), Promotional Literature, undated, http://www.centrolaser.it/en/ lavorazioni.html, Accessed 31 October 2010

12. J. Cedelle, M. Vardelle, and P. Fauchais, Influence of Stainless Steel Substrate Preheating on Surface Topography and on Millimeter- and Micrometer-Sized Splat Formation, Surf. Coat. Technol., 2006, 201(3-4), p 1373-1382

13. C. Zhang, G. Zhang, V. Ji, H. Liao, S. Costil, and C. Coddet, Microstructure and Mechanical Properties of Flame-Sprayed PEEK Coating Remelted by Laser Process, Prog. Org. Coat., 2009, 66, p 248-253

14. P. Laurens, B. Sadras, F. Decobert, F. Arefi, and J. Amouroux, Modifications of Polyether-Etherketone Surface After $193 \mathrm{~nm}$ and $248 \mathrm{~nm}$ Excimer Laser Radiation, Appl. Surf. Sci, 1999, 138-139, p 93-96

15. J.W. Dini, Laser Surface Modification Offers Promise for Various Coating Processes and Substrates, Met. Finish., 1997, 95(10), p 10

16. P.A. Molian, Structural Characterization of Laser-Processed Molybdenum Steel, Mater. Sci. Eng., 1983, 58(2), p 175-180

17. D.H. Meadows, D.L. Meadows, J. Randers, and W. Behrens, The Limits to Growth, Universe Books, New York, 1972, p 205

18. "Registration, Evaluation, Authorisation and Restriction of Chemicals (REACH)" Regulation (EC) No 1907/2006, European Parliament and Council, December 2006

19. E.W. Brooman, Environmentally Preferred Alternatives to Cadmium Coatings for Electrical/Electronic Applications, Environmental Aspects of Electrochemical Technology: Applications in Electronics, M. Datta, J.M. Fenton, and E.W. Brooman, Ed., The Electrochemical Society, Pennington, 1997, p 219-238

20. C.G. Fink, Process of Electrodepositing Chromium and of Preparing Baths Therefor, U.S. Patent 1581188, 1926

21. B. Volesky and Z. Holan, Biosorption of Heavy-Metals, Biotechnol. Prog., 1995, 11(3), p 235-250

22. V.K. Gupta, A.K. Shrivastawa, and N. Jain, Biosorption of Chromium (VI) from Aqueous Solutions by Green Algae Spirogyra Species, Water Res., 2001, 35(17), p 4079-4085

23. T.A. Naguy, Alternative to Chromium Coatings: Wet Deposition Technologies, Proceedings of the Sur/Fin, Chicago, IL, 2004

24. E.W. Brooman, Alternatives to Chromium Coatings: dry Deposition Technologies, Proceedings of the Sur/Fin, Chicago, IL, 2004

25. G. Bolelli, Replacement of Hard Chromium Plating by Thermal Spraying-Problems, Solutions and Possible Future Approaches, Surf. Eng., 2009, 25(4), p 263-269

26. K.O. Legg, M. Graham, P. Chang, F. Rastagar, A. Gonzales, and B. Sartwell, The Replacement of Electroplating, Surf. Coat. Technol., 1996, 81(1), p 99-105

27. E.W. Brooman, Corrosion Performance of Environmentally Acceptable Alternatives to Cadmium and Chromium Coatings: Chromium-Part I, Met. Finish., 2000, 98(7), p 38-43

28. E.W. Brooman, Corrosion Performance of Environmentally Acceptable Alternatives to Cadmium and Chromium Coatings: Chromium-Part II, Met. Finish., 2000, 98(8), p 39-45
29. L. Dubourg and J. Archambeault, Technological and Scientific Landscape of Laser Cladding Process in 2007, Surf. Coat. Technol., 2008, 202(24), p 5863-5869

30. C.P. Paul, H. Alemohammad, E. Toyserkani, A. Khajepour, and S. Corbin, Cladding of WC-12 Co on Low Carbon Steel Using a Pulsed Nd:YAG Laser, Mater. Sci. Eng. A, 2007, 464(1-2), p 170176

31. A. Tukker, Life Cycle Assessment as a Tool in Environmental Impact Assessment, Environ. Impact Assess., 2000, 20(4), p 435456

32. G. Montavon, A. Vardelle, N. Krishnan, P. Ulloa, S. Costil, and H. Liao, Life Cycle Assessment (LCA) of Thermal Sprayed and Chromium Electroplated Coatings, Thermal Spray 2006: Building on 100 Years of Success, B.R. Marple, M.M. Hyland, Y.-C. Lau, R.S. Lima, and J. Voye, Ed., ASM International, Seattle, WA, 2006, p 1399-1405

33. F. Hlawka, E. Bassaine, M. Jourdon, and A. Cornet. Life Cycle Assessment: A New Approach in the Choice of Surface Treatments, Proceedings of the SMT 21, Paris, France, 2007, Published on CD-ROM

34. A. Moign, A. Vardelle, J.G. Legoux, and N.J. Themelis, LCA Comparison of Electroplating and Other Thermal Spray Processes, Expanding Thermal Spray Performance to New Markets and Applications, B.R. Marple, M.M. Hyland, Y.-C. Lau, C.-J. Li, R.S. Lima, and G. Montavon, Ed., ASM International, Las Vegas, NV, 2009, p 1207-1212

35. N. Serres, F. Hlawka, S. Costil, C. Langlade, F. Machi, and A. Cornet, Dry Coatings and Ecodesign. Part 1-Environmental Performances \& Chemical Properties, Surf. Coat. Technol., 2009, 204(1-2), p 187-196

36. N. Serres, F. Hlawka, S. Costil, C. Langlade, and F. Machi, Microstructures and Environmental Assessment of Metallic NiCrBSi Coatings Manufactured Via Hybrid Plasma Spray Process, Surf. Coat. Technol., 2010, 205(4), p 1039-1046

37. P. Lucas, E.A. King, and A. Doraiswamy, Comparison of Photostructural Changes Induced by Continuous and Pulsed Laser in Chalcogenide Glass, J. Optoelectron. Adv. Mater., 2006, 8(2), p 776-779

38. K. Tanaka, Photo-induced Phenomena in Chalcogenide Glasses: Subgap Photon Effects, Proceedings of SPIE 2003, C. Zhu, Ed., Vol. 5061, 2003, p 16-23

39. C.B. Schaffer and E. Mazur, Micromachining Using Ultrashort Pulses from a Laser Oscillator, Opt. Photonics News, 2001, 12(4), p 20-23

40. C. Meneghini and A. Villeneuve, $\mathrm{As}_{2} \mathrm{~S}_{3}$ Photosensitivity by Two-Photon Absorption: Holographic Gratings and Self-Written Channel Waveguides, J. Opt. Soc. Am. B, 1998, 15(12), p 2946-2950

41. L. Landau and E. Lifchitz, Physique statistique, MIR Éditions, URSS, Moscow, 1984, p 592 (in French)

42. G. Petite and P. Daguzan, L'absorption de l'énergie et ses conséquences, École Thématique du CNRS sur l'ablation laser, CNRS Editions, Paris, France, 1996, p 159-218 (in French)

43. J.C. André and A.B. Vannes, Ed., Techniques d'utilisation des photons-principes et applications, DOPEE Diffusion, Avon, France, 1992, p 708 (in French)

44. A. Catherinot, D. Damiani, C. Champeaux, and G. Girault, Photoablation par laser, Laser de Puissance et Traitements des Matériaux, A.B. Vannes, Ed., Presses Polytechniques et Universitaires Romandes, Lausanne, Switzerland, 1991, p 19-57 (in French)

45. D. Baüerle, Laser Processing and Chemistry, 2nd ed., Springer, Heidelberg, Germany, 1996, p 649

46. B.N. Chichkov, C. Momma, S. Nolte, F. Von Alvensleben, and A. Tünnermann, Femtosecond, Picosecond and Nanosecond Laser Ablation of Solids, Appl. Phys. A Mater. Sci. Process., 1996, 63, p 109-115

47. J.F. Ready, Ed., Handbook of Laser Materials Processing, 1st ed., Laser Institute of America, Magnolia Publishing, Inc., Orlando, 2001

48. A.B. Vannes, Ed., Laser et industries de transformation, Techniques de documentation Lavoisier, Paris, 1986 (in French) 
49. J.C. Mallet and R. Fournié, Cours de chimie, Dunod, Paris, France, 1995, p 547 (in French)

50. J.D. McWhirter, Extinction Coefficient and Skin Depth of Alkali Metals from 10 to 1000 nm, Opt. Lasers Eng., 1997, 28, p 305-309

51. R.C. Weast, Ed., Handbook of Chemistry and Physics, 66th ed., CRC Press, Inc., Boca Raton, FL, 1986

52. J. Meijer, K. Du, A. Gillner, D. Hoffmann, V.S. Kovalenko, T. Matsunawa, A. Ostendorf, R. Poprawe, and W. Schulz, Laser Machining by Short and Ultrashort Pulses, State of the Art and New Opportunities in the Age of the Photons, CIRP Ann. Manuf. Technol., 2002, 51(2), p 531-550

53. D. Von Der Linde and K. Sokolowski-Tinten, The Physical Mechanisms of Short-Pulse Laser Ablation, Appl. Surf. Sci, 2000, 154(155), p 1-10

54. H.W. Bergmann, K. Schutte, E. Schubert, and A. Emmel, LaserSurface Processing of Metals for Industrial Applications, Appl. Surf. Sci., 1995, 86(1-4), p 259-265

55. A. Hoffmann and W. Arnold, Calculation and Measurements of the Ultrasonic Signals Generated by Ablating Material With a Q-Switched Pulse Laser, Appl. Surf. Sci, 1996, 96-98, p 71-75

56. P. Peyre, R. Fabbro, L. Berthe, and C. Dubouchet, Laser Shock Processing of Materials, Physical Processes Involved and Examples of Applications, J. Laser Appl., 1996, 8, p 135-141

57. S. Bandyopadhyay, H. Gokhale, J.K. Sarin Sundar, G. Sundararajan, and S.V. Joshi, A Statistical Approach to Determine Process Parameter Impact in Nd:YAG Laser Drilling of IN718 and Ti-6Al-4V Sheets, Opt. Lasers Eng., 2005 43(2), p 163-182

58. J.M. Jouvard, A. Soveja, and N. Pierron, Thermal Modelling of Metal Surface Texturing by Pulsed Laser, Proceedings of the COMSOL Users Conference, 2006, Paris, France

59. R.C.P. Wong, A.P. Hoult, J.K. Kim, and T.X. Yu, Improvement of Adhesive Bonding in Aluminium Alloys Using a Laser Surface Texturing Process, J. Mater. Process. Technol., 1997, 63, p $579-584$

60. D. Neves, A.E. Diniz, and M.S. de Fernandes Lima, Efficiency of the Laser Texturing on the Adhesion of the Coated Twist Drills, J. Mater. Process. Technol., 2006, 179, p 139-145

61. S. Valette, A. Denoirjean, D. Tétard, and P. Lefort, C40E Steel Oxidation Under $\mathrm{CO}_{2}$ : Kinetics and Reactional Mechanism, J. Alloys Compd., 2006, 413, p 222-231

62. A.A. Syed, A. Denoirjean, B. Hannoyer, P. Fauchais, P. Denoirjean, A.A. Khan, and J.C. Labbe, Influence of Substrate Surface Conditions on the Plasma Sprayed Ceramic and Metallic Particles Flattening, Surf. Coat. Technol., 2005, 200, p 2317-2331

63. J. Foldyna, L. Sitek, J. Ščučka, P. Martinec, J. Valíček, and K. Páleníková, Effects of Pulsating Water Jet Impact on Aluminium Surface, J. Mater. Process. Technol., 2009, 209(20), p 61746180

64. S. Costil, H. Liao, O. Chretien, A. Loredo, A. Gammoudi, M. Verdier, and C. Coddet, Influence of Surface Laser Cleaning Combined With Substrate Preheating on Thermal Spray Coating Adhesion, Lasers Eng., 2005, 5-6(15), p 325-345

65. H. Li, "Role d'une ablation laser in situ sur lespropriétés mécaniques d'un revêtement élaboré par projection thermique," $\mathrm{PhD}$ Thesis, Université de Technologie de Belfort-Montbéliard (UTBM), 2006 (in French)

66. V. Barnier, "Etude de l'oxidation de l'aluminium induite par traitement laser $\mathrm{Nd}$ :Yag : conséquences sur les propriétés d'adhérence d'un revêtement d'alumine élaboré par projection thermique," PhD Thesis, Université de Bourgogne, 2006 (in French)

67. H. Li, S. Costil, V. Barnier, R. Oltra, H. Liao, and C. Coddet, Surface Preparation by Laser Cleaning in Thermal Spray-An Introduction to the PROTAL ${ }^{\circledR}$ Process, J. Laser Appl., 2008 , 20(1), p 12-21

68. P. Fauchais, Understanding Plasma Spraying, J. Phys. D Appl. Phys., 2004, 37(9), p R86-R108

69. D.K. Christoulis, S. Guetta, V. Guipont, M.H. Berger, M. Jeandin, L. Berthe, M. Nivard, S. Costil, Y. Ichikawa, K. Ogawa, E. Irissou, J.-G. Legoux, and C. Moreau, Cold Spraying Coupled to Nano-Pulsed Nd-Yag Laser Surface Pre-treatment, J. Therm. Spray Technol., 2010, 19(5), p 1062-1073

70. H. Li, S. Costil, H. Liao, C.-J. Li, M.-P. Planche, and C. Coddet, Effects of Surface Conditions on the Flattening Behaviour of Plasma Sprayed Cu Splats, Surf. Coat. Technol., 2006, 200, p 54355446

71. C.-J. Li, Effects of the Surface Adsorbates on the Morphology of Plasma-Sprayed Splats, Thermal Spray 2005: Explore Its Potential!, E. Lugcheider, Ed., ASM International, Basel, Switzerland, 2005, p 311-319

72. J. Pech, B. Hannoyer, L. Bianchi, A. Denoirjean, and P. Fauchais, Study of Oxide Layer Obtained on 304L Stainless Steel Substrate Heated by a D.C. Plasma Jet, Thermal Spray: A United Forum for Scientific and Technological Advances, C.C. Berndt, Ed., Sept 15-18, 1997 (Indianapolis), ASM International, 1998, p 775-782

73. M. Fukumoto, S. Katoh, and I. Okane, Splat Behaviour of Plasma Sprayed Particles on Flat Surface, Thermal Spraying: Current Status and Future Trends, A. Ohmori, Ed., High Temperature Society of Japan, Kobe, Japan, 1995, p 353-358

74. Y. Danlos, "Etude de l'association lasers-projection thermique pour l'optimisation de revêtements," $\mathrm{PhD}$ Thesis, Université de Technologie de Belfort-Montbéliard (UTBM), 2009 (in French)

75. V. Barnier, O. Heintz, D.E. Roberts, R. Oltra, and S. Costil, XPS and SIMS Study of Aluminium Native Oxide Modifications Induced by Q-Switched Nd:YAG Laser Treatment, Surf. Interface Anal., 2006, 38, p 406-409

76. V. Barnier, S. Costil, H. Li, C. Coddet, and R. Oltra, Study of Aluminium Oxidation Induced by a Q-switched Nd:YAG Laser Treatment and Its Influence on the Adhesion Properties of a Plasma-Sprayed Alumina Coating, Thermal Spray 2007: Global Coating Solutions, B.R. Marple, M.M. Hyland, Y.-C. Lau, C.-J. Li, R.S. Lima, and G. Montavon, Ed., ASM International, Pekin, China, 2007, p 335-340

77. M. Bray, A. Cockburn, and W. O'Neil, The Laser Assisted Cold Spray Process and Deposit Characterisation, Surf. Coat. Technol., 2009, 203, p 2851-2857

78. S. Costil, G. Montavon, H. Liao, and C. Coddet, Laser Hybrid Plasma Spray Processes: Tools to Adjust Coating Structural Characteristics, High Temp. Mater. Process. (Redding, CT), 2006, 10(3), p 327-364

79. S. Costil, H. Liao, A. Gammoudi, and C. Coddet, Influence of Surface Laser Cleaning Combined With Substrate Preheating on the Splat Morphology, J. Therm. Spray Technol., 2005, 14(1), p 31-38

80. Y. Danlos, S. Costil, X. Guo, H. Liao, and C. Coddet, Ablation Laser and Heating Laser Combined to Cold Spraying, Surf. Coat. Technol., 2010, 205(4), p 1055-1059

81. S. Sasaki, Tribological Properties of Coating Films Synthesised by Laser Assisted Plasma Spraying, Surf. Eng., 1997, 13(3), p 238-242

82. J.H. Ouyang and S. Sasaki, Microstructure and Tribological Characteristics of $\mathrm{ZrO}_{2}-\mathrm{Y}_{2} \mathrm{O}_{3}$ Ceramic Coatings Deposited by Laser-Assisted Plasma Hybrid Spraying, Tribol. Int., 2002, 35(4), p 255-264

83. S.O. Chwa and A. Ohmori, Microstructures of $\mathrm{ZrO}_{2}-8 \mathrm{wt} \%$ $\mathrm{Y}_{2} \mathrm{O}_{3}$ Coatings Prepared by a Laser Hybrid Spraying Technique, Surf. Coat. Technol., 2002, 153(2-3), p 304-312

84. S.O. Chwa and A. Ohmori, Thermal Diffusivity and Erosion Resistance of $\mathrm{ZrO}_{2}-8 \mathrm{wt} \% \mathrm{Y}_{2} \mathrm{O}_{3}$ Coatings Prepared by a Laser Hybrid Spraying Technique, Thin Solid Films, 2002, 415(1-2), p 160-166

85. Z. Zhou, H. Shirasawa, N. Eguchi, and A. Ohmori, Microstructures and Characterization of Zirconia-Yttria Coatings Formed in Laser and Hybrid Spray Process, J. Therm. Spray Technol., 1999, 8(3), p 405-413

86. G. Antou, G. Montavon, F. Hlawka, A. Cornet, C. Coddet, and F. Machi, Evaluation of Modifications Induced on Pore Network and Structure of Partially Stabilized Zirconia Manufactured by Hybrid Plasma Spray Process, Surf. Coat. Technol., 2004, 180-181, p 627-632

87. G. Antou, G. Montavon, F. Hlawka, A. Cornet, C. Coddet, and F. Machi, Modification of Ceramic Thermal Spray Deposit 
Microstructures Implementing In Situ Laser Remelting, Surf. Coat. Technol., 2003, 172(2-3), p 279-290

88. N. Serres, F. Hlawka, S. Costil, C. Langlade, F. Machi, and A. Cornet, Combined Plasma Spray and In Situ Laser Melting Treatment of NiCrBSi Powder, J. Opto. Adv. Mater., 2010, 12(3), p 505-510

89. N. Serres, F. Hlawka, S. Costil, C. Langlade, and F. Machi, Microstructures of Metallic NiCrBSi Coatings Manufactured Via Hybrid Plasma Spray Process, Thermal Spray: Global Solutions for Future Applications, B.R. Marple, A. Agarwal, M.M. Hyland, Y.C. Lau, C.J. Li, R.S. Lima, and G. Montavon, Ed., DVS-Berichte, Singapore, 2010, p 283-288

90. N. Serres, F. Hlawka, S. Costil, C. Langlade, and F. Machi, Corrosion Behavior of NiCrBSi Alloy Coatings Manufactured Via In Situ Plasma Spray-Laser Re-Melting Process, Thermal Spray: Global Solutions for Future Applications, B.R. Marple, A. Agarwal, M.M. Hyland, Y.C. Lau, C.J. Li, R.S. Lima, and G. Montavon, Ed., DVS-Berichte, Singapore, 2010, p 662-667

91. I. Etsion, State of the Art in Laser Surface Texturing, J. Tribol., 2005, 127, p 248-253

92. R. Ranjan, D.N. Lambeth, M. Tromel, P. Goglia, and Y. Li, Laser Texturing for Low-Flying-Height Media, J. Appl. Phys., 1991, 69(8), p 5745-5747

93. L. Blunt and S. Xiao, The Use of Surface Segmentation Methods to Characterise Laser Zone Surface Structure on Hard Disc Drives, Wear, 2010, doi: 10.1016/j.wear.2010.06.014

94. A. Kovalchenko, O. Ajayi, A. Erdemir, G. Fenske, and I. Etsion, The Effect of Laser Surface Texturing on Transitions in Lubrication Regimes During Unidirectional Sliding Contact, Tribol. Int., 2005, 38(3), p 219-225

95. L. Rapoport, A. Moshkovich, V. Perfilyev, A. Gedanken, Y. Koltypin, E. Sominski, G. Halperin, and I. Etsion, Wear Life and Adhesion of Solid Lubricant Films on Laser-Textured Steel Surfaces, Wear, 2009, 267(5-8), p 1203-1207

96. Y. Wan and D.S. Xiong, The Effect of Laser Surface Texturing on Frictional Performance of Face Seal, J. Mater. Process. Technol., 2008, 197(1-3), p 96-100

97. I. Etsion and G. Halperin, A Laser Surface Textured Hydrostatic Mechanical Seal, Seal. Technol., 2003, 3, p 6-10

98. C. Vincent, G. Monteil, T. Barriere, and J.C. Gelin, Texturation de surface par laser sur un matériau hétérogène, $18^{\text {eme }}$ Congrés Français de Mécanique, Grenoble, France, 2007 (in French)

99. M.R.H. Knowles, G. Rutterford, D. Karnakis, and A. Ferguson, Micromachining of Metals, Ceramics and Polymers Using Nanosecond Lasers, Int. J. Adv. Manuf. Technol., 2007, 33(1-2), p 95-102

100. G. Lallemand, G. Jacrot, E. Cicala, and D.F. Grevey, Grooving by Nd:YAG Laser Treatment, J. Mater. Proc. Technol., 2000, 99(1-3), p 32-37

101. A.A. Voevodin and J.S. Zabinsk, Laser Surface Texturing for Adaptative Solid Lubrication, Wear, 2006, 261, p 1285-1292

102. L. Tunna, W. O'Neill, A. Khan, and C. Sutcliffe, Analysis of Laser Micro Drilled Holes Through Aluminium for Micro-Manufacturing Applications, Opt. Lasers Eng., 2005, 43, p 937-950

103. J. Qi, K.L. Wang, and Y.M. Zhu, A Study on the Laser Marking Process of Stainless Steel, J. Mater. Process. Technol., 2003, 139(1-3), p 273-276

104. L.M. Vilhena, M. Sedlaček, B. Podgornik, J. Vižintin, A. Babnik, and J. Možina, Surface Texturing by Pulsed Nd:YAG Laser, Tribol. Int., 2009, 42(10), p 1496-1504

105. A. Soveja, "Modélisation du processus de texturation par faisceau laser: approches expérimentale et numérique", PhD Thesis, Université de Bourgone, 2007 (in French)

106. B.S. Yilbas, Parametric Study to Improve Laser Hole Drilling Process, J. Mater. Process. Technol., 1997, 70(1-3), p 264273

107. A. Soveja, E. Cicala, D. Grevey, and J.M. Jouvard, Optimisation of TA6V Alloy Surface Laser Texturing Using an Experimental Design Approach, Opt. Lasers Eng., 2008, 46, p 671-678

108. C.A. Biffi, N. Lecis, B. Previtali, M. Vedani, and G.M. Vimercati, Fiber Laser Microdrilling of Titanium and Its Effect on Material Microstructure, Int. J. Adv. Manuf. Technol., 2010, doi: 10.1007/s00170-010-2918-6
109. H.C. Man, Q. Wang, and X. Guo, Laser Surface Microdrilling of Ti and Laser Gas Nitrided Ti for Enhancing Fixation of Dental Implants, Opt. Lasers Eng., 2010, 48, p 583-588

110. A. Lamraoui, S. Costil, C. Langlade, and C. Coddet, Laser Surface Texturing (LST) Treatment Before Thermal Spraying: A New Process to Improve the Substrate-Coating Adherence, Surf. Coat. Technol., 2010, 205(1), p S164-S167

111. A. Lamraoui, Rapport region December 2009, LERMPSUTBM, Belfort, France, Unpublished Work, 2009 (in French)

112. A. Lamraoui, Rapport Region November 2010, LERMPSUTBM, Belfort, France, Unpublished Work, 2010 (in French)

113. I.A. Almeida, W. de Rossi, M.S.F. Lima, J.R. Beretta, G.E.C. Nogueira, N.U. Wetter, and N.D. Vieira, Jr., Optimization of Titanium Cutting by Factorial Analysis of Pulsed Nd:YAG Laser Parameters, J. Mater. Process. Technol., 2006, 179(1-3), p 105-110

114. D. Triantafyllidis, L. Li, and F.H. Stott, Crack-Free Densification of Ceramics by Laser Surface Treatment, Surf. Coat. Technol., 2006, 201, p 3163-3173

115. L. Bradley, L. Li, and F.H. Stot, Flame-Assisted Laser Surface Treatment of Refractory Materials for Crack-Free Densification, Mater. Sci. Eng. A, 1999, 278(1-2), p 204-212

116. C. Batista, A. Portinha, R.M. Ribeiro, V. Teixeira, M.F. Costa, and C.R. Oliveira, Surface Laser-Glazing of Plasma-Sprayed Thermal Barrier Coatings, Appl. Surf. Sci., 2005, 247(1-4), p 313319

117. R. Krishnan, S. Dash, C. Babu Rao, R.V. Subba Rao, A.K. Tyagi, and B. Raj, Laser Induced Structural and Microstructural Transformations of Plasma Sprayed $\mathrm{Al}_{2} \mathrm{O}_{3}$ Coatings, Scr. Mater., 2001, 45(6), p 693-700

118. R. Krishnan, S. Dash, R. Kesavamoorthy, C. Babu Rao, A.K. Tyagi, and B. Raj, Laser Surface Modification and Characterization of Air Plasma Sprayed Alumina Coatings, Surf. Coat. Technol., 2006, 200(8), p 2791-2799

119. G. Antou, G. Montavon, F. Hlawka, A. Cornet, C. Coddet, and F. Machi, Modification of Thermal Barrier Coating Architecture by In Situ Laser Remelting, J. Eur. Ceram. Soc., 2006, 26(16), p 3583-3597

120. H. Pokhmurska, B. Wielage, T. Lampke, T. Grund, M. Student, and N. Chervinska, Post-Treatment of Thermal Spray Coatings on Magnesium, Surf. Coat. Technol., 2008, 202(18), p 4515-4524

121. E. Fernández, J.R. García, J.M. Cuetos, and V. Higuera, Behaviour of Laser Treated $\mathrm{Cr}$, Ni Coatings in the Oxidative Atmosphere of a Steam Boiler, Surf. Coat. Technol., 2005, 195(1), p 1-7

122. M. Laribi, N. Mesrati, A.B. Vannes, and D. Treheux, Adhesion and Residual Stresses Determination of Thermally Sprayed Molybdenum on Steel, Surf. Coat. Technol., 2003, 166(2-3), p 206-212

123. N. Serres, F. Hlawka, S. Costil, C. Langlade, and F. Machi, Corrosion Properties of In Situ Laser Remelted NiCrBSi Coatings Comparison With Hard Chromium Coatings, J. Mater. Process. Technol., 2011, 211(1), p 133-140

124. R. González, M. Cadenas, R. Fernández, J.L. Cortizo, and E. Rodríguez, Wear Behaviour of Flame Sprayed NiCrBSi Coating Remelted by Flame or by Laser, Wear, 2007, 262(3-4), p 301-307

125. Z. Bergant and J. Gru, Quality Improvement of Flame Sprayed, Heat Treated, and Remelted NiCrBSi Coatings, J. Therm. Spray Technol., 2009, 18(3), p 380-391

126. S. Abdi and S. Lebaili, Alternative to Chromium, a Hard Alloy Powder NiCrBCSi (Fe) Coatings Thermally Sprayed on 60CrMn4 Steel. Phase and Comportements, Phys. Procedia, 2009, 2(3), p 1005-1014

127. J.F. Li, L. Li, and F.H. Stott, Comparison of Volumetric and Surface Heating Sources in the Modeling of Laser Melting of Ceramic Materials, Int. J. Heat Mass Transf., 2004, 47(6-7), p $1159-1174$

128. C. Li, Y. Wang, S. Wang, and L. Guo, Laser Surface Remelting of Plasma-Sprayed Nanostructured $\mathrm{Al}_{2} \mathrm{O}_{3}-13 \mathrm{wt} \% \mathrm{TiO}_{2}$, Coatings on Magnesium Alloy, J. Alloys Compd., 2010, 503, p 127-132

129. Y. Wang, C. Li, L. Guo, and W. Tia, Laser Remelting of Plasma Sprayed Nanostructured $\mathrm{Al}_{2} \mathrm{O}_{3}-\mathrm{TiO}_{2}$ Coatings at Different Laser Power, Surf. Coat. Technol., 2010, 204(21-22), p 3559-3566 
130. J. Iwaszko, Surface Remelting Treatment of Plasma-Sprayed $\mathrm{Al}_{2} \mathrm{O}_{3}+13 \mathrm{wt} \% \mathrm{TiO}_{2}$ Coatings, Surf. Coat. Technol., 2006, 201(6), p 3443-3451

131. L. Bradley, L. Li, and F.H. Stott, Characteristics of the Microstructures of Alumina-Based Refractory Materials Treated With CO and Diode Lasers, Appl. Surf. Sci., 1999, 138-139, p 233-239

132. A. Ibrahim, H. Salem, and S. Sedky, Excimer Laser Surface Treatment of Plasma Sprayed Alumina-13\% Titania Coatings, Surf. Coat. Technol., 2009, 203(23), p 3579-3589

133. M.F. Morks, C.C. Berndt, Y. Durandet, M. Brandt, and J. Wang, Microscopic Observation of Laser Glazed Yttria-Stabilized Zirconia Coatings, Appl. Surf. Sci., 2010, 256, p 6213-6218

134. S.O. Chwa and A. Ohmori, The Influence of Surface Roughness of Sprayed Zirconia Coatings on Laser Treatment, Surf. Coat. Technol., 2001, 148(1), p 87-94

135. V. Cannillo, L. Lusvarghi, A. Sola, and M. Barletta, PostDeposition Laser Treatment of Plasma Sprayed TitaniaHydroxyapatite Functionally Graded Coatings, J. Eur. Ceram. Soc., 2009, 29(15), p 3147-3158

136. J. Hanchi and N.S. Eiss, Jr., Dry Sliding Friction and Wear of Short Carbon-Fiber-Reinforced Polyetheretherketone (PEEK) at Elevated Temperatures, Wear, 1997, 203-204, p 380-386

137. V. Hnatowicz, V. Havranek, J. Bocan, A. Mackova, J. Vacik, and V. Svorcik, Modification of Poly(ether ether ketone) by Ion Irradiation, Nucl. Instrum. Methods Phys. Res. B, 2008, 266(2), p 283-287

138. Q. Wang, Q. Xue, H. Liu, W. Shen, and J. Xu, The Effect of Particle Size of Nanometer $\mathrm{ZrO}_{2}$ on the Tribological Behaviour of PEEK, Wear, 1996, 198, p 216-219

139. T. Palathai, J. Tharajak, and N. Sombatsompop, Hardness, Adhesion Index and Microstructure of PEEK Coating on $\mathrm{Al}$ or Fe Substrate by LVOF Flame Spray, Mater. Sci. Eng. A, 2008, 485(1-2), p 66-73

140. Z.P. Lu and K. Friedrich, On Sliding Friction and Wear of PEEK and Its Composites, Wear, 1995, 181-183, p 624-631

141. P.J. Rae, E.N. Brown, and E.B. Orler, The Mechanical Properties of Poly(ether-ether-ketone) (PEEK) With Emphasis on the Large Compressive Strain Response, Polymer, 2007, 48 p 598-615

142. Polymer Data File: Polyether Ether Ketone-PEEK, Tangram Technology Ltd., http://www.tangram.co.uk/TI-Polymer-PEEK. html, Accessed 31 October 2010

143. PEEK Spec Datasheet, San Diego Plastics Inc., http://www. sdplastics.com/peek.html, Accessed 31 October 2010

144. G. Zhang, S. Leparoux, H. Liao, and C. Coddet, Microwave Sintering of Poly-Ether-Ether-Ketone (PEEK) Based Coatings Deposited on Metallic Substrate, Scr. Mater., 2006, 55, p 621-624

145. I. Corni, N. Neumann, S. Novak, K. König, P. Veronesi, Q. Chen, M.P. Ryan, and A.R. Boccaccini, Electrophoretic Deposition of PEEK-Nano Alumina Composite Coatings on Stainless Steel, Surf. Coat. Technol., 2009, 203, p 1349-1359

146. K. Patel, C.S. Doyle, D. Yonekura, and B.J. James, Effect of Surface Roughness Parameters on Thermally Sprayed PEEK Coatings, Surf. Coat. Technol., 2010, 204, p 3567-3572
147. I. Corni, N. Neumann, D. Eifler, and A.R. Boccaccini, Polyetheretherketone (PEEK) Coatings on Stainless Steel by Electrophoretic Deposition, Adv. Eng. Mater., 2008, 10(6), p 559-564

148. H. Liao, E. Beche, and C. Coddet, On the Microstructure of Thermally Sprayed 'PEEK' Polymer, Thermal Spray: Meeting the Challenges of the 21st Century, C. Coddet, Ed., ASM International, Nice, France, 1998, p 25-29

149. A. Soveja, P. Sallamand, H. Liao, and S. Costil, Improvement of Flame Spraying PEEK Coating Characteristics Using Lasers, J. Mater. Process. Technol., 2011, 211(1), p 12-23

150. L. Simonin and H. Liao, Characterization of Flame-Sprayed PEEK Coatings by FTIR-ATR, DSC and Acoustic Microscopy, Macromol. Mater. Eng., 2000, 283, p 153-162

151. H. Liao, C. Coddet, and L. Simonin, Mechanical Properties of Thermal Spray PEEK Coatings, Thermal Spray 2001: New Surface for a New Millennium, C.C. Berndt, K.A. Khor, and E.F. Lugscheider, Ed., ASM International, Singapore, 2001, p 315320

152. J. Li, C. Hanlin Liao, and C. Coddet, Friction and Wear Behavior of Flame-Sprayed PEEK Coatings, Wear, 2002, 252, p 824-831

153. H. Li, S. Costil, V. Barnier, R. Oltra, O. Heintz, and C. Coddet, Surface Modifications Induced by Nanosecond Pulsed Nd:YAG Laser Irradiation of Metallic Substrates, Surf. Coat. Technol., 2006, 201, p 1383-1392

154. G. Zhang, W.Y. Li, M. Cherigui, C. Zhang, H. Liao, J.M. Bordes, and C. Coddet, Structures and Tribological Performances of PEEK (Poly-Ether-Ether-Ketone)-Based Coatings Designed for Tribological Application, Prog. Org. Coat., 2007, 60, p 39-44

155. K.H. Tan, C.K. Chua, K.F. Leong, C.M. Cheah, P. Cheang, M.S. Abu Bakar, and S.W. Cha, Scaffold Development Using Selective Laser Sintering of PolyetheretherketoneHydroxyapatite Biocomposite Blends, Biomaterials, 2003, 24, p 3115-3123

156. G. Zhang, H. Liao, H. Yu, S. Costil, S.G. Mhaisalkar, J.M. Bordes, and C. Coddet, Deposition of PEEK Coatings Using a Combined Flame Spraying-Laser Remelting Process, Surf. Coat. Technol., 2006, 201, p 243-249

157. J.M.P. Coelho, M.A. Abreu, and C.F. Rodrigues, Methodologies for Determining Thermoplastic Films Optical Parameters at $10.6 \mu \mathrm{m}$ Laser Wavelength, Polym. Test, 2004, 23, p 307312

158. L. Dosser, K. Hix, K. Hartke, R. Vaia, and M. Li, Transmission Welding of Carbon Nanocomposites With Direct-Diode and Nd:YAG Solid State Lasers, Photon Processing in Microelectronics and Photonics, January 26-29, 2004 (San Jose, CA), SPIE, Vol 5339, 2004, p 465-474

159. A. Buchman, H. Dodiuk, M. Rota, and J. Zahavi, Preadhesion Treatment of Thermoplastic Adherends Using Excimer Laser, Int. J. Adhes. Adhes., 1991, 11(3), p 144-149

160. E. Wurzberg, A. Buchman, E. Zylberstein, Y. Holdengraber, and H. Dodiuk, Preadhesion Laser Surface Treatment of Polycarbonate and Polyetherimide, Int. J. Adhes. Adhes., 1990, 10(4), p 254-262

. 